\title{
The biological meaning of preferences on the human mate market
}

\author{
Bogusław Pawłowski \\ Department of Anthropology, University of Wrocław, Kuźnicza 35, \\ 50-138 Wrocław, Poland, E-mail: bogus@antropo.uni.wroc.pl
}

\begin{abstract}
Factors, which universally influence mate choice decisions, are: age, physical appearance, and resources. Different evidence of the biological relevance of these three factors on the human mate market is presented. The sexspecific preferences for partner's age reflect such values as Fisherian reproductive potential and fecundity for females and life expectancy related to the length of further time of paternal investment for males. Physical attractiveness is analyzed as a marker of female's age, and in the case of both sexes as a marker of hormone level, heterozygosity and therefore immunocompetence. Because attractiveness connotes genetic quality of a prospective partner and indicates higher fitness for offspring, it is not an arbitrary trait. Resources of males are discussed as being important for females because they assure good paternal investment and therefore higher reproductive success. Human flexibility in age and physical attractiveness preferences is also examined in relation to ecological conditions. The evidence presented here indicates that the factors influencing human mate choice decisions can be honest, biologically relevant cues of reproductive value of a prospective partner.
\end{abstract}

KEY WORDS human mate preferences, reproductive potential, age preferences, physical attractiveness, resources, height, WHR

Prz. Antropol. - Anthropol. Rev. (2000), vol. 63, pp. 39-72, Figs. 6. ISBN 83-86969-60-1, ISSN 0033-2003

\section{Introduction}

According to evolutionary theory, humans should select mating partners that enable them to enhance their reproductive success. Since each sex has different reproductive conditions and physiological constraints from the other they pursue different reproductive strategies.
Males are concerned about female fecundity and the chances of a potential mate to bear successfully pregnancy and lactation. Females are concerned about male socio-economic status (SES), which is strongly related with abilities to protect a female and her offspring and to provide resources for them. This means that as in many other species, human mating is not 
a random process, both sexes using some sex-specific cues which indicate a prospective mate's biological value or the way a mate's traits can influence "fitness" of their offspring. The preferences of both sexes are well known from a long time, but the scientific confirmation of these in different cultures, and the biological meaning of these preferences have been unraveled only in the recent decades (e.g., BuSs [1989], SYMONS [1979], PERUSSE [1993]). Both evolutionary psychology, which concentrates on universality of evolutionary determined human behavior, and human behavioral ecology, which emphasizes flexibility in behavioral adaptations in dependence of changing physical and social environments, try to answer the questions about biological mechanisms determining human mate choice strategies.

We know that mate choice is a complex process studied not only by biologists but also by psychologists, demographers and the scientists modeling market dynamics. The approach related to market mechanisms of mate decisions recently gained much interest [NOË \& HAMMERSTEIN 1995; NOË et al. 2001]. As in all markets, in the human mate market there is usually an unequal distribution of "partner resources" and thus potential for transactions. If females are in shorter supply than males the mating market is asymmetric. This can explain the prevalence of female choice and why they can play off males against one another, forcing them to demonstrate their quality in costly displays [HAMMERSTEIN 2001]. Mate choice can be influenced not only by the supply of the potential mates, but also by the environmental conditions, individual's experience of his or her mate market value and by the strategy an indi- vidual pursues (i.e., short-term versus long-term mate strategy). Many pieces of information are usually gathered in order to decide with whom to mate. The choice of mate is usually a trade-off between demands of a person and demands of his/her potential mates. Demands of both sexes are due to their preferences and these do not need to be the same. Although some individuals can behave in a non-adaptive way (i.e., having preferences for traits which are not biologically relevant or even disadvantageous), one can ask whether usually both sexes make mate decisions which are related to their future reproductive success.

Research on mate preferences usually relies on: self-report of preferences [BUSS 1989, PAWŁOWSKI \& DUNBAR 2001], the attributes requested in ads [BERECZKEI et al. 1997; HARRISON \& SAEED 1977; KENRICK \& KEEFE 1992; PAWŁOWSKI \& DUNBAR 1999a], the actual responses to ads [BAIZE \& SCHROEDER 1995], or statistics on mate behavior [PERUSSE 1993, 1994]. Since the results obtained by these various ways are similar, one can reject the objection that results obtained on the bases of lonely hearts columns, which are used very often in this paper, cannot be a reliable source of information on the human mate market. Using anonymous selfreports independently from ads, BAIZE $\&$ SCHROEDER [1995] showed that the personality self-descriptions in the ads are honest and not just a strategic selfpresentation. Studies on mate preferences consistently show what traits are valued by both sexes in a prospective mate and confirm evolutionary predictions on the dynamic of human mate markets.

Analyses of contents of personal advertisements showed that the words used 
in these ads reflect just a few key dimensions that have strong evolutionary valency (i.e., age, attractiveness, resources, family commitment, social skills) [BERECZKEI et al. 1997; GREENLESS \& MCGREW 1994; PAWŁOWSKI \& DUNBAR 1999a; WAYNFORTH \& DUNBAR 1995; WIEDERMAN 1993]. Here I concentrate on the traits, which have been universally shown as those having the strongest impact on mate choice decisions in many societies: age, body shape, facial features and resources. These traits appear to be used in mate choice decisions independently of mate strategy (short- or long-term), ecological conditions and to a great extent, of the adult sex ratio. Some of these important traits, as for example female's age, are rather indisputable indicators of reproductive potential. For others, e.g., for physical attractiveness, there are a few competing theories (Fisherian "run away" selection, good-genes sexual selection, sensory bias) trying to explain their biological meaning on the human mate market and/or the way preferences spread in a population (see review in THORNHILL \& GRAMMER [1999]). Combining different lines of evidence I would like to show that the most important traits influencing human mate choice decisions are usually trustworthy cues of a prospective mate's reproductive value.

\section{Materials}

The original results presented in this paper are based on three different data sets. The first data set comprises 1045 (505 males and 540 by females) heterosexual personal advertisements placed in the Observer newspaper's Soulmates columns in eight issues published between autumn 1995 and spring 1996 (the details are in PAWŁOWSKI \& DUNBAR [1999a]). From here on, they will be referred to either as the data from the "Observer" or just as BLHD (British lonely-hearts data).

The second data set comes from the "Cmok" matrimonial bureau from Wrocław, Poland. All the personal advertisements from this data set were placed in "Gazeta Robotnicza" (now "Gazeta Wrocławska") between 1994 and 1996. This data set comprises 2008 full advertisements (957 by males and 1051 by females). From here on, they will be referred to as either the personal advertisements from Wroclaw or just as WLHD (Wrocław lonely-hearts data).

The third data set comes from questionnaires completed by 892 mothers with the last born baby between 9 and 16 months and collected in 11 outpatients' surgeries for healthy children and in 5 GP practices in Wrocław. These data were collected between spring 1998 and spring 1999. Out of 892 women, those who gave birth to twins, did not specify their age, pre-pregnancy weight, height or waist or hip circumferences were excluded. It yielded a sample of 728 women.

\section{Age and mate market value}

Age is a well proven, universal and indisputable trait taken into account on the human mate market. It is a trait of crucial biological or reproductive significance. There are a number of studies on age preference by both sexes in contemporary societies [KENRICK \& KEEFE 1992; THIESSEN et al. 1993; WAYNFORTH \& DUNBAR 1995]. Although age 
is a much more important mate choice criterion for males, it is also significant for females. The difference between sexes comes from the fact that human female has shorter or "closed" reproductive period in her life. This period is much longer, or "opened" for human males. For all populations female fertility rate at age 30-34 years is around $85 \%$ of the rate at age $20-24$ years. It further declines to nearly $35 \%$ of the 20-24 years baseline at age 40-44 and to $0 \%$ of this at age 50 years (after JONES [1995]). Whereas, the decline for men is much less steeper once age of wife and duration of marriage are controlled for to $90 \%$ for men at $45-50$ and to $80 \%$ for those over 55 [GOLDMAN \& MONTGOMERY 1989]. The important biological meaning of female age is reflected in very explicit male age preferences for females. Bride wealth in traditional societies (e.g., in Kipsigis) is negatively related with the bride age; moreover, it is negatively correlated with the age of menarche [BORGERHOFF MULDER 1988]. This is evidence for higher value of those girls who have longer reproductive prospects. In all modern societies studied adult men also prefer younger women (see e.g., KENRICK \& KEEFE [1992], THIESSEN $e t$ al. [1993], WAYNFORTH \& DUNBAR [1995]). Because a female's reproductive potential declines with age rapidly, one should also expect that the preferred age of a male's partner should change as he ages. With increasing age, males prefer relatively younger females than themselves. This means that men in their twenties seek women of the similar age or younger only by 2-4 years, and men in their forties and fifties would like to find a woman on average 6-10 years younger than themselves [BERECZKEI et al. 1997; KENRICK \& KEEFE 1992; THIESSEN et al. 1993; WAYNFORTH \& DUNBAR 1995; WIEDERMANN 1993]. Analysis of the data from the "Observer" lonely-hearts columns confirmed the same pattern (Fig.1A). Although the differences in mean age of partner sought are significant for both sexes across 4 age classes, the effect is much more pronounced for men (One-way ANOVA $F=24.5 d f=3$, $p<0.0001$ vs. $F=3.33, p<0.02$ for women), and in post-hoc Bonferroni tests there is only one significant difference between women in their 20's and 30 's and almost all significant differences for men (with the exception of men in their 40's compared with those in their 50's). There was also a consistent decrease in the percentage of advertisers specifying age sought from $46.2 \%$ for women in their 20 's to only $12.8 \%$ for women in their 50 's (in fact only 5 women of those in 50's specified age sought). The most demanding men in this respect were those in their 30's $(46.7 \%$ specified age sought). Altogether, more men than women specified age sought $\left(\chi^{2}=8.7, d f=1, p<0.004\right)$, which reflects the high significance of female's age in the mate market. The data from the personal advertisements from "Gazeta Robotnicza" confirm that with age, preferred age difference increases only for males (Fig. 1B). The same pattern was found in studies curried out in Germany, Holland and India [KENRICK \& KEEFE 1992]. This indicates that men would like to find a woman within her reproductively active period of life. KENRICK \& KEEFE [1992] showed that sex differences in age choice are consistent across generations. 

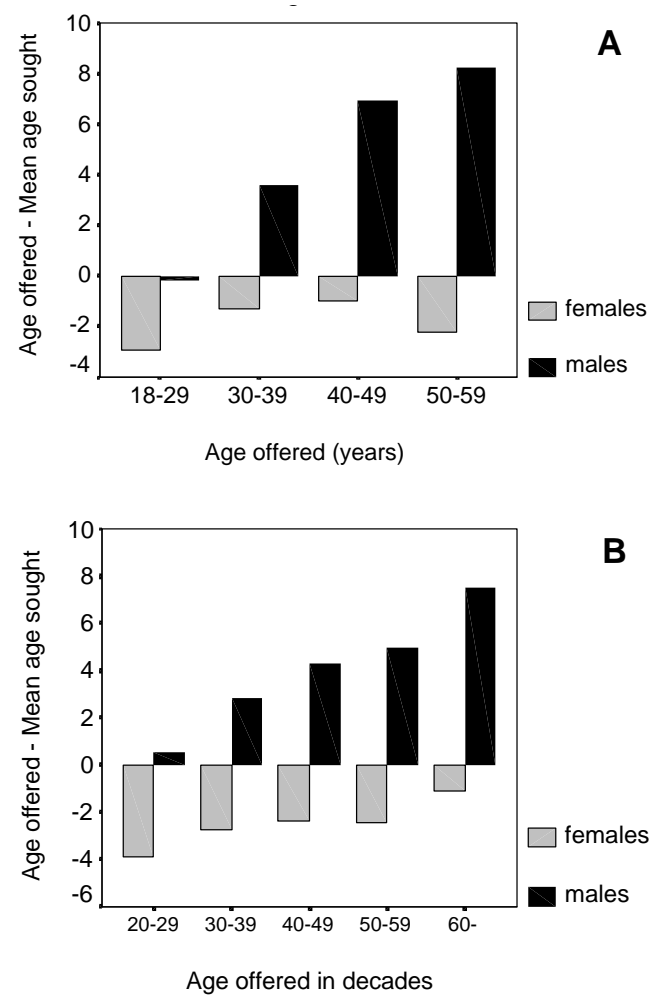

Fig. 1. The differences between age offered and mean age sought plotted against age classes for both sexes. The results obtained on the basis of data from: (A) soulmates columns from the "Observer" (UK), (B) singles ads from the "Cmok" marriage bureau which appeared in "Gazeta Robotnicza" (Poland)

Knowing how important age is, females can manipulate the situation with the information on their own age. Significantly fewer women than men state their age in the lonely-hearts advertisements [GREENLESS \& MCGREW 1994]. When analyzing such advertisements in the "Observer" newspaper, PAwŁOWSKI \& DUNBAR [1999a] found that women who do not reveal their own age have a different mate seeking strategy to those who do reveal their age. The authors called this phenomenon the "hidden age" effect. Women who do not reveal their age or give it only roughly (in decades) are more demanding in their criteria for a potential mate than other females of similar age. In terms of demands, women hiding their age are similar to those very demanding young women in their 20's. This effect was not detected for men. What is more, men who do not reveal an age in their advertisement, usually demand less of their prospective partner than other men do. This means that they do not seek traits such as attractiveness, sense of humour or intelligence as often as the other men do. PAWŁOWSKI \& DUNBAR [1999a] showed that with age women revealed more often only their approximate age (e.g., in pentads or in decades). Among advertisements made by women up to 29 years of age, there was not a single case of a woman who specified her age in decade or pentad. The popular wisdom that one should not talk about a woman's age is just a reflection of the biological meaning of this trait on the mate market. The strong positive correlation $(r=0.94)$ between mean number of partners per year and agespecific fertility for unmarried and unattached women of all ages from Canada reflects female age significance for the opposite sex [PERUSSE 1994].

Men prefer women with the highest Fisher's reproductive value (expected number of offspring produced in the future) independently of age, socioeconomic status (SES) and their reproductive strategy, that is women entering the reproductive stage of life or highly fecund ones. With respect to the length of time in which their mate will be able to give them offspring, males prefer very young females (this usually corresponds to the long-term relationship strategy). When pursuing the short-term relation- 
ship strategy, males can easily accept high current fecundity at the cost of lower reproductive potential. In that case there is no need to invest in a female and wait until she reaches physiological reproductive maturity or high fecundity. Older men who have lower life expectancy than the length of the whole female reproductive period prefer women in the middle of their reproductive period (i.e., in their 30's). These men can value higher current fecundity than perspectives of a longer period fertility in the women. There is also the risk that if such a man dies before the end of his partner's reproductive period, she can have a child with another man. This poses the risk of lowering the investment in or neglecting his children (not to mention the risk of abusing the child by new partner's mate). The other partial explanation of males' age preferences can be due to the fact that in present-day populations of industrialized countries, the reproductive value peaks around the age of 25 and is lower for younger women. Multiple regression analysis revealed that although both current fecundity and Fisher's reproductive value contribute to the variance in female market value, the former appeared to be more important variable in the data from the "Observer", which were analyzed by PAWŁOWSKI \& DUNBAR [1999b]. JONES [1995] also suggests that although males would like to mate with very young and beautiful females, in some cases they can avoid engaging with them in a long-term relationship, because in such relationships males can be more vulnerable to cuckoldry and economic exploitation.

The fact that teenage males [KENRICK 1994] and those in their 20's [BERECZKEI et al. 1997] prefer older partners than themselves is consistent with the impor- tance of cues to female fecundity and undermine the hypothesis that males always prefer younger and easily dominated females.

Because of open male reproductive potential, age has a different meaning for men. This is because male traits that are so important on the mate market (e.g., wealth or social status) are usually positively correlated with age. This explains why females prefer men older than themselves. Male fertility declines with age as a consequence of decrease in sexual activity rather than of the decrease in sperm quality [VERMEULEN 2000]. In men older than 75 years, only $25 \%$ have subnormal levels of plasma testosterone. Despite the fact that reproductive potentials also decrease with age for males [VERMEULEN \& KAUFMAN 1995; VERMEULEN 2000], their age is rather more important in relation to the decrease of their further life expectancy. PAWŁOWSKI \& DUNBAR $[1999 b]$ showed that the dynamics of the mate market depends on the male's economic situation and his life expectancy. Since this is not a trivial parameter (lower life expectancy, higher chances of death and leaving the woman with children financially unsupported), women in their early reproductive stages may prefer men with fewer resources but auguring good prospects for the future and with high life expectancy. This assures the female of long care by a male over her and her offspring. It is particularly important when the duration of child dependence is very long and the cost of raising it is relatively high (as it happens in humans). Figure 2 shows how the "market value" (defined for each age cohort of each gender as the proportion of advertisers seeking individuals of that cohort by the number of members of that 


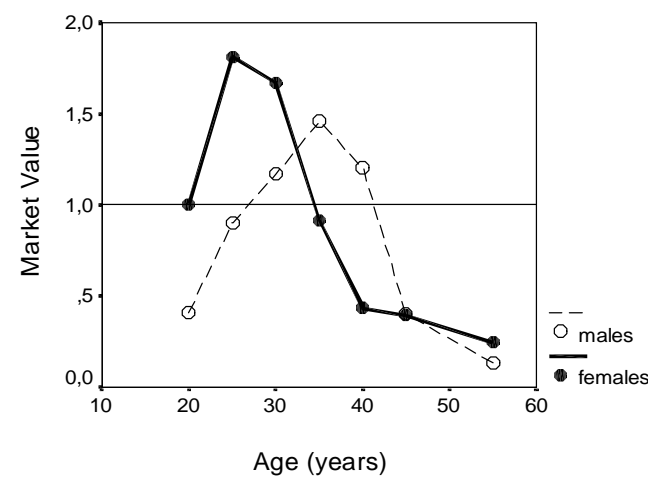

Fig. 2. Market value of males and females plotted against age. Market value is a selection ratio reflecting advertisers' preference for each age class relative to the number of individuals available in that age class in the advertising population. Advertisers' preferences are those expressed by reproductive age individuals (defined as 20-44 years in the case of females, 20-59 years in the case of males - see text for details). The horizontal line at a market value of 1.0 defines the point at which preferences balance availability (after PAWŁOWSKI \& DUNBAR [1999b])

cohort advertising) depends on age. Although women prefer (on average) older men, their preferences are humpshaped with respect to male age, as suggested by WAYNFORTH \& DUNBAR [1995] and clearly seen in Figure 2. A multiple regression analysis by PAWŁOWSKI \& DUNBAR [1999b] yielded that male market value is influenced by male income and the probability that male will still be married after 20 years. The second component depends on both: the probability that the male will be still alive after 20 years, and the probability that the male will not be divorced during that time.

BAIZE \& SCHROEDER [1995] and PAWŁOWSKI \& DUNBAR [2001] showed that both sexes know what traits are sought by the opposite sex quite well, and this means that they respond to market demands correctly. Older men would of course be interested in females even 20 or more years younger than themselves but since the choice is mutual, they cannot easily get what they want because they must deal with female preference as well [KENRICK \& KEEFE 1992]. It is worth noting that less than $50 \%$ of advertisers in the lonely heart columns specify the age sought. For instant in the data from the "Observer" only $37.8 \%$ of females and $42.4 \%$ of males specified the range of age sought. This means that when analyzing preferred age in prospective partner in this way, we should have in mind that we take into consideration only some of the most demanding advertisers. Age is very potent predictor of personal demands on the mate market. Women tend to seek most traits during their reproductive period of life (20-39 years of age). Meanwhile, men seek more traits in their 30's and 40's [WAYNFORTH \& DUNBAR 1995]. Figure 3 presents how advertisers change their demands with age. The "demandness" is calculated as a difference between total amount of traits offered and traits sought for both sexes (data from the "Observer"). One-way ANOVA yields no significant differences in the mean difference between traits offered and sought for 4 men's age classes $(N=369, F=1.12 d f=3, p<0.3)$ and highly significant decrease in the same variable for women $(N=367, F=7.9$ $d f=3, p<0.0001)$. The fact that women who are older seek relatively fewer traits in a prospective partner and offer more, which is not the case for men, is another proof of the females' awareness of changes in their "mate market" value.

To sum up, age is a significant factor that is taken into consideration by males because it is related to female reproductive potential and fecundity. Females also consider age because it is related to the 


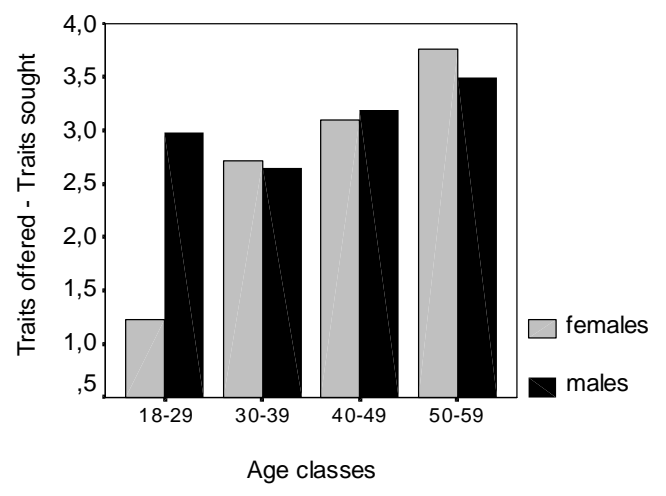

Fig. 3. Mean differences between the number of total traits offered and traits sought ("demandness") for both sexes in dependence on advertisers' age classes

male life expectancy and correlates with such substantial traits as the man's wealth and his social status. As RAJECKI et al. [1991] showed, age of advertiser appeared to be the only significant factor that affected the number of responses received, with older men and younger women receiving the most replies. All that means that one cannot analyze the supply and demand commodities on the human mate market independently of age.

\section{Biological relevance of physical attractiveness}

In the last decades, social psychologists and biologists showed how important in western culture is something we attribute to physical attractiveness. One's job prospects, friendship, investment from others and mateship opportunities, all have been shown to be positively influenced by physical attractiveness [THORNHILL \& GRAMMER 1998]. In a controlled study, WALSTER et al. [1966] showed that the only one successful predictor of the satisfaction from the blind date was physical attractiveness. Since many later studies replicated the same effect, biologists and psychologists started to wonder what might be the ultimate basis of physical attractiveness and judgements about it. Contrary to the assumption that criteria of attractiveness are highly culture specific and hence cross-culturally variable, it appeared that attractiveness is rated as important in all cultures studied. Individuals who are rated as attractive in their culture also tend to be rated as attractive by members of other cultures [CUNNINGHAM 1986; CUNNINGHAM et al. 1995; THORNHILL \& GANGESTAD 1993]. The experiments conducted by LANGLOIS et al. [1987] showed that even 2-month-old babies, when exposed to pictures of women spent more time looking at faces rated by adults as attractive. Furthermore, this held true even across racial boundaries, i.e., white babies looked longer at black women which were rated as attractive by adult black men, and vice versa.

Although the concept of physical attractiveness is quite complex, here I would like to deal only with body shape and facial features as those considered as the most related to physical attractiveness. The universality of perceiving some features as attractive indicates that they should be related to the individual's biological quality, e.g., health, hormone levels or general reproductive potential. If attractiveness did not reflect any "biological value", one should expect different accidental traits to be considered as attractive in different societies. FISHER [1930] argued that when in some population a small majority has preference for some trait in the opposite sex, this preference can spread very quickly ("run-away selection"). The initial preponderance could be created through 
nothing more than chance fluctuation (this does not imply that such trait needs to be related to any biological quality). If an individual with a "fashionable" trait is chosen as a mate more often by the opposite sex, it would be worthwhile to mate with him/her in order to pass the genes of attractiveness to the offspring of the opposite sex (in the female case it would be an "attractive sons" effect). This behavior should increase reproductive success in subsequent generations. With the Fisherian "run-away selection" hypothesis, attractive traits could be even maladaptive. Although this way of creating "attractive" features is possible, here I show evidence that it does not have to be a main reason, which lay behind the preference of some physical traits perceived as attractive. If however, these particular traits are selected for because they are adaptive and in some way "fitness" related, the Fisherian mechanism could also enhance the selection for such traits. "Good genes" sexual selection is a second, and with the "good provider" hypothesis (emphasizing parental care and protection), the now probably prevalent hypothesis of attractiveness [CRONIN 1991]. It postulates that individuals with traits perceived as attractive have not only greater reproductive success but also higher fitness, e.g., related to their survival rate, growth and development or to parasite resistance. Morphological signals considered as attractive are usually relatively costly to produce and hence usually honest and uncheatable. The "arm race" between signaling by one sex and detecting truthful, i.e., fitness related signals by the other sex, have resulted in physical traits perceived as attractive usually honestly advertising mate value [ZAHAVI \& ZAHAVI 1997]. On this basis one can analyze many features perceived as attractive by the opposite sex as "fitness" related signals. The traits perceived as attractive depend of course on such ecological factors as climate, food distribution or predatory risk. Here I would like to analyze the biological relevance of the physical traits, which seem to be universal and the most important on the human mate market.

\section{Biological relevance of female's body shape attractiveness}

\section{Body fat amount}

In traditional societies female "plumpness" is considered as more beautiful than sliminess [SMUTS 1992]. BORGERHOFF MULDER [1988] found that Kipsigis males pay higher bridewealth for "plump" than for "skinny" girls. Often in food shortages in pre-industrial societies, surplus calories stored in body fat increased the chances of survival and successful reproduction. However, only some females (usually from higher social strata) could afford to store so much fat. Thus the attractiveness of plump females can be easily explained by adaptive male aesthetic preference for mates displaying both high status and energy reserves that can support reproduction in difficult periods [LOW et al. 1987]. The other reason for preferring females with higher body mass index (BMI) in traditional societies can be the correlation between mother's and her newborn's amount of fat [FORBES 1987]. Newborn size and fatness could differentiate survival chances in past societies. Women giving birth to heavier and fatter newborns could have had higher reproductive success [PAWŁOWSKI 1998]. Yet, in western societies the opposite preference seems to 
prevail [JAŁKIEWICZ 1997; SMUTS 1992; TASSINARY \& HANSEN 1998]. Does this discrepancy indicate a cultural or social base for attractiveness canons related to the amount of body fat? Body fat amount in fact is the perfect example of an aesthetic preference dependent upon environmental conditions. Firstly, men supposedly have a notion of female body shape attractiveness as a function of environmental and nutritional conditions present in the society they live in [ANDERSON et al. 1992]. Men's preference may be also directed to body type corresponding with higher female family status. In an environment where there is no risk of starvation or any serious seasonal fluctuations in food acquisition, storing fat internally is not the best solution. It is because any fat storage increasing the weight puts an additional load on the cardiovascular system and increases the risk of hypertension [HUANG et al. 1998; STEYN et al. 2000], and coronary heart disease [CHOINIERE $e t$ al. 2000; QVIST et al. 1996]. The risk of endometrial cancer is also significantly elevated for women with BMI higher than 24.5 [HACHISUGA et al. 1998]. In studying changes in art across human evolution (in Prehistoric and historic times as well) we might correlate a preference for sculptures or paintings presenting "plump" females with at least seasonal food acquisition problems. What is more, in affluent modern society body fat in females is negatively correlated with social status and with the food quality consumed by women [SMUTS 1992]. Secondly, in wealthier societies life expectancy increases dramatically and extends far behind the end of the female reproductive period. This means that with the long life expectancy and with higher status, men in their 30's and 40 's can be attracted to the signs of females with high reproductive potential. The preference for slimness can reflect the preference for females of young age (for those who have this youth related trait). It may mean that in such societies cues of female youthfulness, which are related to high reproductive potential, can be valued higher than cues of fecundity by the majority of men. BMI is positively correlated with age across the reproductive period of life in females. ROLLANDCACHERA et al. [1991] showed in the French population that BMI increases between 12 and 65 years for both sexes. LAKE et al. [1997] showed in the longitudinal British data that even between 16 and 33 years, BMI increases by 3.2-4.5 units for all parental BMI categories. The data from Wrockaw for women in their reproductive period of life confirm that BMI is age dependent $(t=7.46$, $p>0.00001, r=0.26$ ) (see Figure 4) and that this relationship does not depend on female's parity. What is interesting is that there is no such correlation for nulliparous women with university education $(r=0.0, t=0.09, p<0.93, N=124)$ and a relatively high one for women with a lower education level $(r=0.32, t=6.48$, $p<0.00001, N=362$ ). One interpretation is that due to the life style of highly educated women, BMI is not an age-related cue for these women. On the other hand, with the life style of lower educated women and probably in prevalent previous life conditions, BMI could have been quite a good sign of female's age.

Apart from the ecological reasons for preferring females with different amount of body fat, there are also some other methodological points, which should be addressed. In many studies showing the 


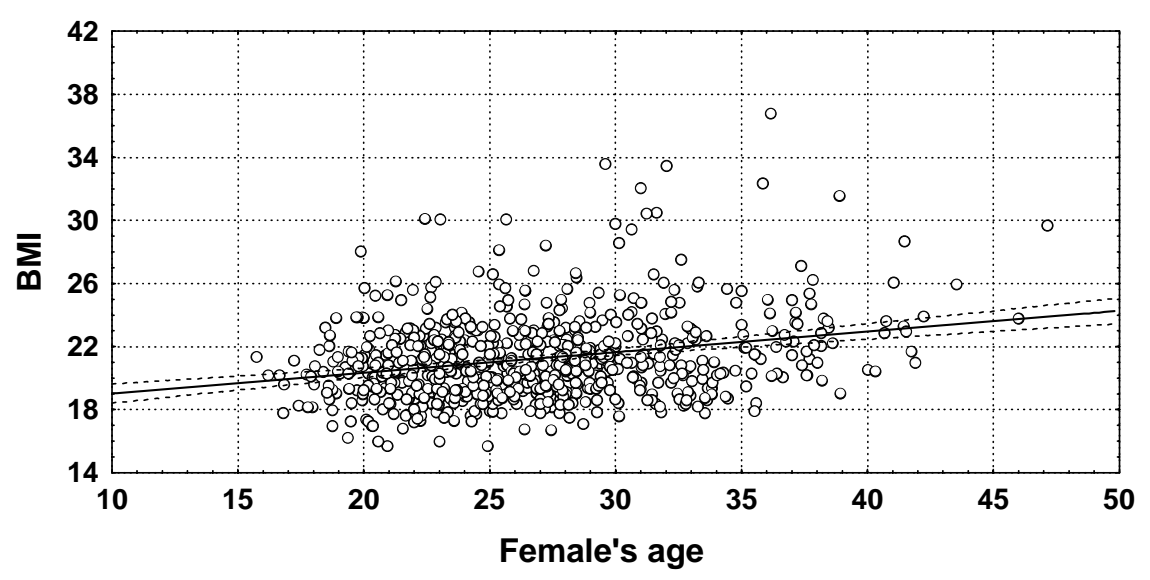

Fig. 4. Correlation between BMI and age for women in the fertile period of life. Correlation coefficient $r=0.26$; BMI $=17.72+0.13 \times$ Female's age

strong preference for slim girls, e.g., JAŁKIEWICZ [1997], TASSINARY \& HANSEN [1998], the male raters were very young (high school or college students). For such males, female reproductive potentials can be more important than female fecundity. Female slimness reflects young age and therefore high female reproductive potential. If male raters were older, they could be more concerned about current female fecundity and therefore would prefer rather moderate (or normal) weight females. Studying personal advertisements from the lonely hearts columns in Hungary, BERECZKEI et al. [1997] found that relatively many men of mean age 38.4 years $(s d=10.8)$ requested "plumpness" in the prospective partner.

\section{Fat distribution}

Apart from the amount of fat there is another independent body shape trait related to the female reproductive success, and it is fat distribution which can be measured by waist to hip ratio (WHR). A few studies showed that both females and males judge as more attractive female silhouettes with lower WHR [SINGH 1993a,b; FURNHAM et al. 1997]. Figure 5 presents six silhouettes of women in two weight classes and with 3 different WHRs. On similar figures researches carried out studies on female body shape preferences (SINGH [1993a] used 12 silhouettes with four different WHR (0.7-1.0) in three weight categories, and TASSINARY \& HANSEN [1998] used even 27 silhouettes). Is the preference for lower WHR due to some female "biological value" or just a matter of cultural preference unrelated to female's fitness? There is at least some indirect and direct evidence that WHR reflects female reproductive potential. WHR is inversely related to health condition [BJÖRNTORP 1988; LEIBEL et al. 1989; FOLSOM et al. 1993] and to the level of sex steroids and gonadotropins, and positively with the timing of puberty in girls [DERIDDER et al. 1990]. Health and endocrinological status can of course be an indirect sign of female reproductive potential. The relation of WHR with 

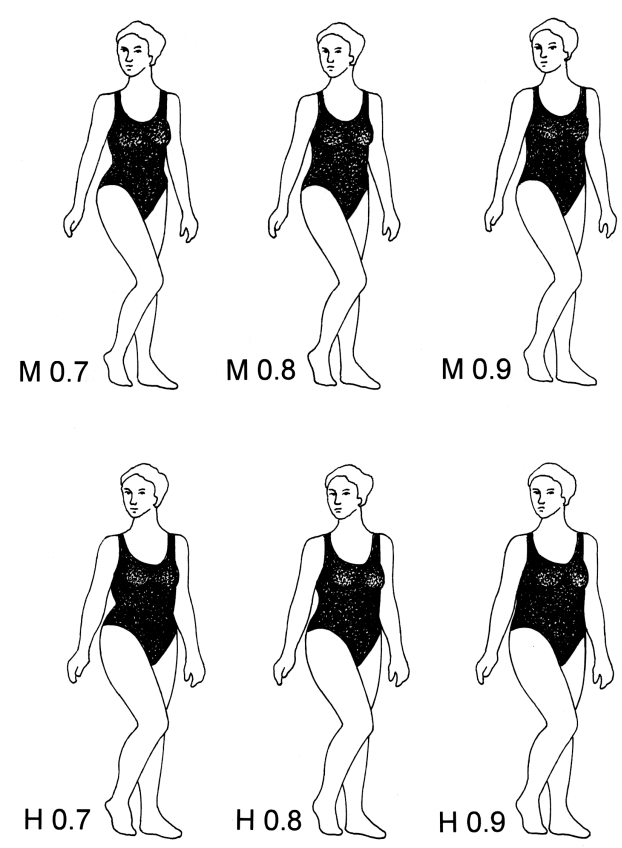

Fig. 5. An example of stimulus figures used in the studies on female body shape preferences. Here there are 6 silhouettes of women in two weight classes (M-moderate and H-heavy) and with 3 different WHR (from 0.7 to 0.9 ). SINGH [1993a] used 3 weight categories (underweight, normal, overweight) and within each category four silhouettes with different WHRs $(0.7-1.0)$

female "reproductive value" was shown in the program of artificial insemination in the Netherlands by ZAADSTRA et al. [1993]. They found that with the increase of WHR there was dramatic decrease in the probability of successful pregnancy. Higher WHR and lower BMI have been found also to be related to the later onset of reproduction (i.e., the first live birth) [KAYE et al. 1990], and to the shorter reproductive period of life.

Another measure of the reproductive relevance of the preference for lower WHR can be neonatal weight. Both in traditional and contemporary western societies birth weight can be a good predictor of infant mortality [CHASE 1969; KoOPS et al. 1982;
SAPPENFIELD et al. 1987] and morbidity [DESCRILLI et al. 1983]. This means that birth weight can be a trait, which measures female reprofpctive ability. Pawłowski and Dunbar ${ }^{1}$ showed that birth weight is inversely related to mother's pre-pregnant WHR. They also showed that only in the lowest range of weight (and in lower range of stature) pre-pregnant BMI is a better predictor of neonatal weight than pre-pregnant WHR. The latter is instead a better predictor of pregnancy outcome for women of moderate weight. They conclude that the preference for females with higher BMI (see also TOVEE \& CORNELISSEN [1999]) rather than for wasp-waisted body shape in short statured and light populations (e.g., in Hadza from Tanzania [WETSMAN \& MARLOWE 1999] or in Matsigenka from Peru [YU \& SHEPARD JR. 1998]) is biologically justified. Although undermining the universality of the preference for lower WHR in females, the results obtained on Hadza and Matsigenka populations do not undermine biological relevance of the aesthetic preferences related to the female body shape (see also another explanation by MANINNG et al. [1999]). The results indicate that in dependence of female body size, the "hierarchy" of important physical cues of female reproductive potential can differ.

Another confirmation of WHR as a cue of female "biological quality" can be the negative relationship between WHR and breast-feeding duration? ${ }^{2}$ It is well proven that longer breast-feeding has advantages over shorter duration of

\footnotetext{
${ }^{1}$ Waist:hip ratio as a measure of fitness in women (submitted to Nature)

${ }^{2}$ B. Pawłowski, Pre-pregnant WHR and breast feeding duration: the support for biological meaning of female's WHR attractiveness (in preparation)
} 
breast-feeding. Breast-feeding is known to reduce infant mortality and morbidity worldwide [CUNNINGHAM et al. 1991]. It assures adequate passive immunity for a longer time. This is particularly important in high pathogen environments. Infants who receive sustained passive immunity through breast-feeding have lower morbidity and mortality rate [MCDADE \& WORTHMAN 1999]. Longer lactation is associated with optimal growth and development and even with the higher intelligence of a child (review by GOLDING et al. [1997]). In preindustrial societies, adequate length of breast-feeding is very important for child well being and for longer interbirth intervals (this assures a baby better parental investment). The relationship between WHR and lactation time appears also to depend on female's pre-pregnancy weight in the same way as results obtained by Pawłowski \& Dunbar (see footnote 1) on female's WHR and her offspring neonatal weight. This supports the notion that different aesthetic preferences for female body shape are biologically relevant. No wonder then, that apart from general descriptors, body shape in a prospective partner is sought by males 10 times more often than by females [WIEDERMAN 1993].

These results do not mean however that one could not expect any nonadaptive trends in body fashion. Firstly we can expect some response to the new evolutionary conditions. This response can be either adaptive in the populational context (e.g., mechanisms protecting against overpopulation) or can be an effect of new disturbing physical and/or social environmental factors. It is not easy to reconcile mechanisms of population ecology with adaptation at the indi- vidual level. Secondly, we can deal with frequency dependent differentiation of behavior, which is not under strong natural selection. In that case, i.e., if not under strong selective pressure, evolution can produce diversity and only from the longer perspective one can assess adaptiveness of different preferences.

\section{Male's body stature and attractiveness}

Female body features which count in the human mate market usually reflect female chances to give birth, and to pass successfully pregnancy and lactation. Apart from these body features which seem to reflect genetic quality and can be equally important for both sexes, preferred male body features are related to the male's efficiency in intramale competition, their ability to provide food and to protect offspring and female. Such a male's trait, which has been shown consistently in many studies as an advantageous in mateship, is male stature.

The preference for taller men was shown in the hit rate, i.e., in the number of responses males receive for their personal advertisements. Taller men receive more responses than shorter ones [LYNN \& SHURGOT 1984]. It was confirmed on PLHD when controlling for age and education. PAWŁOWSKI et al. [2000] showed that taller men have higher chances to have at least one child. Since there are no differences in the probability of having a child or in the number of children for shorter and taller married men, one can presume that the crucial factor here is the likelihood of having a partner and not the reproductive physiology differences between taller and

${ }^{3}$ B. Pawłowski \& S. Kozieł, Height and relative weight as traits influencing number of responses to personal advertisements (in preparation) 
shorter men. This is supported by the fact that bachelors are on average significantly shorter than married men [PAWŁOWSKI et al. 2000]. Females indeed desire male romantic partners who are relatively taller [PIERCE 1996]. The general preference for taller males can be confirmed by the fact that all the United States presidents save two have been of above average height and with just one exception the taller candidate for president has always won [POTTS \& SHORT 1999]. There are however limits to the linear relation between male's stature and attractiveness. GRAZIANO et al. [1978] found that although women prefer on average taller men they do not desire too tall men. It is possible that PAWŁOWSKI et al. [2000] obtained the consistent result on the preference of taller men on the mate market because to avoid confounding pathological effects their excluded men taller than $1.92 \mathrm{~m}$.

Is the female's preference for taller males just a fashion or it is in some way related to the higher biological value of taller males? In several cohort studies in different countries stature appeared to be inversely related to the mortality rate from coronary heart disease (e.g., KEE et al. [1997], PECK \& VAGERO [1989], SILVENTOINEN et al. [1999], but see also LIAO et al. [1996], who did not find an inverse height-heart disease relation) and from respiratory diseases (e.g., ALLBECK \& BERGH [1992], WAALER [1984]). SILVENTOINEN et al. [1999] showed that in Finland tall men are healthier than short men. Short conscripts have also increased overall morbidity due to psychiatric and musculoskeletal diagnoses compared with taller conscripts [TUVEMO et al. 1999]. General mortality rate is also inversely related with height [WAALER
1984]. According to PECK \& VAGERO [1989] connection between height and mortality is established when young and is not an effect of factors related to SES during adulthood. These results indicate that female's preference for taller men can be justified by the fact that height can be a cue of male's health and his higher expectancy of life. Since male body mass correlates positively with male body symmetry [MANNING 1995], it may signal honestly immunocompetence. This means that bigger body size can also be the morphological sign of developmental stability.

The other biological reason of attractiveness of taller males is due to their mental abilities, higher chances of upward social mobility and in general belonging to higher SES. Those traits are highly valued by human females because they guarantee higher paternal investment in their offspring and therefore secure higher reproductive success. Mean intellectual performance increases continuously with height [TEASDALE et al. 1991; TUVEMO et al. 1999]. As TUVEMO et al. [1999] showed, short conscripts scored worse than taller conscripts in assessment of psychological functioning during mental stress, and were evaluated as less suitable for leadership positions. The prevalence of poor cognitive performance declines with increasing height also for older men [АВBOT et al. 1998]. Abbot and his coworkers claim that if poor condition and stress in childhood can influence height, it can also influence brain growth.

The positive relationship between height and intellectual abilities per se does not need to be adequate reason for perceiving taller men as attractive. It has to be translated into some reproductive 
advantage of such men. It appears that taller brothers tend to get better education and therefore attain higher SES [BIELICKI \& CHARZEWSKI 1983; SCHUMACHER \& KNUSSMAN 1979]. Many other data confirm that male's education and SES level is positively related to his height [BIELICKI \& WALISZKO 1992; MEYER \& SELMER 1999]. Whether it is genetically linked with some traits facilitating upward social mobility for taller individuals or with between-sib environmental (prenatal or postnatal) inequalities (e.g., BIELICKI \& CHARZEWSKI [1983]), it does not matter in terms of females' preference for taller males. Final body height can inform either about individual's genetic quality or environmental factors (both pre- and postnatal) a male was raised up in. The most important is that taller males have higher chances of attaining higher SES and secure better paternal investment. Height has been found to be universally positively associated with power and status [ELLIS 1992]. If behind socio-economic success lays also higher genetic heritability it is better but by no means necessary, to justify any biological meaning of females' preference for taller males.

\section{Face attractiveness}

In addition to conveying information about sex and sexual maturity, facial secondary sexual traits may be designed to advertise phenotypic and genetic quality [THORNHILL \& GANGESTAD 1993]. The face was shown to be an important source of attraction not only for humans but also for nonhuman primates, sheep and goats [KENDRICK et al. 1998]. Since the naked (unhaired) human face conveys both verbal and non-verbal information, it attracts attention very often. It is easier to judge face color, skin structure or such subtle features as asymmetry. The human face probably gains even more importance in the clothed cultures where other parts of the body are not often exposed. In such societies the face becomes a crucial visible signal of a prospective mate's value. No wonder the human face has gained a lot of attention and seems to be very important in all social contexts including mate choice decisions. Although it is well known that expressive and grooming features of face also influence judgements about facial attractiveness [CUNNINGHAM et al. 1990], here I would like to concentrate only on facial morphology.

\section{Face attractiveness as a marker of age}

Since age is an important sign of human female reproductive potential one should expect that some physical features attributed to youth should be perceived as attractive particularly in females. Although natural selection did not "design" a psychological mechanism to detect female age per se it promoted the evolution of the physical characteristics e.g., smooth, clear skin, good muscle tone, lustrous hair, full lips [SYMONS 1979] that were reliably correlated with youth [BUSS 1989]. This means that some standards of attractiveness must have evolved in correspondence to these youthful features. Due to improved diet, health care and cosmetics, women in their 30's and 40 's in western culture are able to retain enough youthful appearance to stimulate men's psychological mechanisms for sexual attractiveness despite the fact that those women are in the middle or at the end of their reproductive period. As WIEDERMAN [1993] rightly put it "it is not a woman's age which is a 'turn off' for men, but rather how old she looks". 
Using photographs, MATHES et al. [1985] showed that compared with younger women, older ones were judged less physically attractive by both sexes. They did not find any differences with age when judging male attractiveness. Undoubtedly unwrinkled and unblemished face skin can be a universal marker of youthfulness. Given that attractiveness varies with age, JONES [1995] postulates that neotenous features (e.g., relatively big eyes, small nose, full lips) may be a component of facial attractiveness. Using three methods (photographs, models and drawings of faces), JONES [1995] showed that female faces with such youth markers as large eyes, small nose and full lips in relation to face height are perceived as more attractive. The results for male faces in this study were inconsistent. This intersexual difference only supports the thesis that age related facial features are much more important for females (but see LANGLOIS et al. [1994]). Neoteny hypothesis by Jones was confirmed by PERRETT et al. [1998], who showed that feminized women's faces were preferred over average shapes of a female face. This may mean that when faced with contradictory signals, raters may use some hierarchy of importance of the face stimuli. The most important would be probably age related face features and less important, those features which are cues of hormone levels or immunocompetence.

SYMONS [1995b] claims that higher level of growth hormone in maternal circulation during pregnancy may permanently "coarsen" or masculinize female facial features. He suggests that certain facial proportions may index parity and indicate female age related mate value. Since at the end of the reproduc- tive period estrogen level declines, testosterone can masculinize the female face.

There is no doubt that face can inform about female's age and therefore about her reproductive potential with great accuracy. This relationship proves of biological relevance in perceiving as attractive those facial features, which reflect female's youth.

\section{Face attractiveness as a marker of hormone level}

Sex specific steroid hormone proportion markers seem to be important signs not only of the reproductive competence but also of the high genotype quality. In the adaptive reallocation hypothesis of WEDEKIND \& FOLSTAD [1994], it is supposed that androgens allocate energy and resources between reproductive functions and immunological defenses. If there is a trade-off between survival and reproduction, those males who despite of competition between metabolic energy, which needs to be spent on immunological defense and the energy on sexual display, were able to invest in sexual displays, should have good genes. This seems to be true both for high testosterone level in males and high estrogen level in females [THORNHILL \& MOLLER 1997]. Thus, markers of high estrogen level may also reliably signal high female immunocompetence.

Although more important for females, features related to steroid hormone levels are significant on the mate market also for males. Both, body shape and facial traits seem to be related to sex specific hormone proportion. CUNNINGHAM et al. [1990] found that maturity features of prominent cheekbones and a large chin in males are positively linked to the attractiveness. According to him, these male 
traits are related to androgen level. It is relatively high testosterone at sexual maturity that leads to the growth of lower face and jaw, cheekbones and brow ridges as well as projection of the central face between the brow and bottom of the nose [SYMONS 1995a]. The bizygomatic breadth relationship with the androgen to estrogen level explains probably why the only facial trait that was significantly preferred by males was narrower face width in females [STRZAŁKO \& KASZYCKA 1988, 1992]. It is high estrogen level at puberty that prevents growth of this part of face, but yields increased lip size. It seems then that the preference for women with narrower faces can be justified by their more feminine hormone status. CUNNINGHAM [1986] found that narrow female cheek width was even associated with perceived fertility. Rated as attractive, larger lower jaw in the male face correlates positively with testosterone level during puberty in males and is due to the higher number of sexual experiences they have and the predictor of onset of heterosexual activity [MAZUR et al. 1994]. Since testosterone is an immunosupressor [FOLSTAD \& KARTER 1992], its amount honestly signals male quality. This is because the higher hormone level needed to produce attractive features simultaneously handicaps disease resistance, and can be afforded by individuals of good immunocompetence. Related to testosterone level, strong jaws or broad cheekbones are features, which contribute to perceived facial dominance in men. These features may indicate physical strength. Since facial dominance can be the predictor for high status in male dominance hierarchies [MUELLER \& MAZUR 1997], then in the resource-based mating system of humans it signals quali- ty relevant to male fitness. Controlling other factors MUELLER \& MAZUR [1997] showed that only facial features related with dominance have a positive effect on the total number of children.

Some studies on male facial attractiveness however indicate that apart from such maturity features as prominent cheekbones and large chin, females assess as attractive also such neotenous features of male face as greater eye area, higher and wider eyes or smaller overall nose size [CUNNINGHAM et al. 1990]. Since the ideal male face seems to convey both cuteness and ruggedness, CUNNINGHAM et al. [1990] suggest that such a mixture of facial traits may elicit female responses of both nurturant affection and respect. Yet, when authors asked women to evaluate male photographs on babyish and masculinity facial appearance scales, they found that baby face ratings were negatively correlated with judgements of desirability to marry and perceived masculinity (angular face, bigger chin, thicker eyebrows) was positively correlated with attractiveness, desirability to date and marry.

\section{Immunological competence, good genes and facial attractiveness}

As has been already mentioned, facial features, which are signs of higher level of sex hormones, can mark also immunological competence and therefore effective pathogen resistance (the immunocompetence model). The application of this model to the human mate market is supported by the fact that the value placed on physical attractiveness in mate choice correlates positively with the prevalence of parasites across human societies [GANGESTAD \& BUSS 1993]. In the process of development all organisms 
face with different harmful conditions and have only limited amount of energy, which could be allocated for different purposes. Thus, those who despite spending a lot of energy on overcoming factors disturbing development and growth, can afford energy on bilateral symmetry have supposedly good genes. This means that small random deviations from perfect bilateral symmetry of morphological structures (called fluctuating asymmetry - FA) can indicate the developmental instability of an individual [VAN VALEN 1962]. Symmetrical features seem to be an indicator of good genes. Composite faces made from many individual photos, which have facial features being near the mean, are rated more attractive [LANGLOIS, ROGGMAN 1990; KUJAWA 1998; KUJAWA \& STRZAŁKO 1998; THORNHILL \& GANGESTAD 1993]. STRZAŁKO \& KASZYCKA [1988, 1992] showed also that for majority of facial traits, middle values were preferred. The fact that physical attractiveness is related to the most common morphological traits in a population, STRZAŁKO \& KASZYCKA [1992] explain by the conformity of these traits to the species standard. I would argue, however, that what is common or the most popular in a population can be perceived as the most successful. It is because it represents genes that were passed in the highest number of copies. SYMONS [1995a] also emphasizes that the preference for the average mean could be explained by lower functionality of extreme facial features. THORNHILL \& GANGESTAD [1993] claim that facial averageness can mark genetic quality because averageness is likely to covary positively with heterozygosity (see Fig. 6 - a face produced by the "averaging procedure" - it is an example of the face

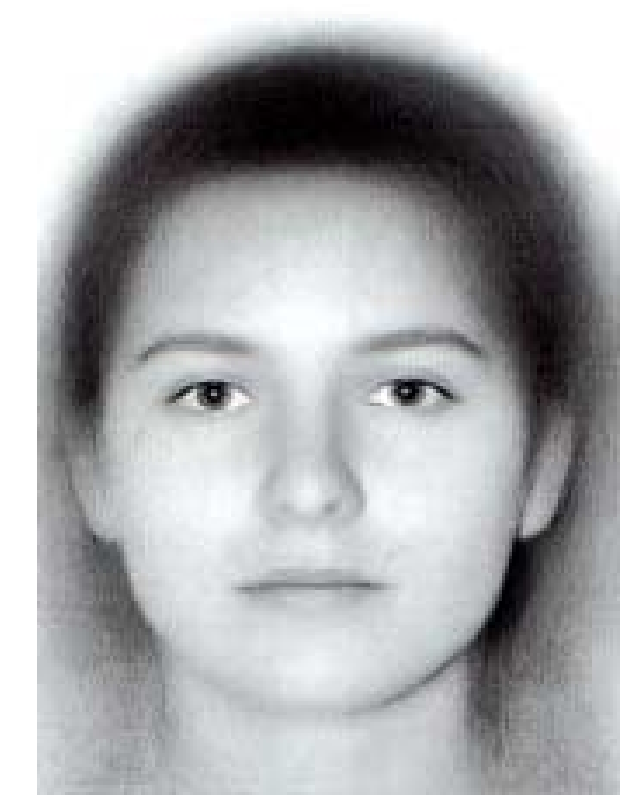

Fig. 6. An example of the face produced by "mathematical" averaging of 128 female faces. Considered as a very attractive, this face presents positive relationship between attractiveness, and both averageness and facial symmetry (after KUJAWA \& STRZAŁKO [1998])

which is perceived as attractive). Whereas higher protein heterozygosity is related with better parasite-resistance genetic make-up. However, Grammer and Thornhill found that this is the case only for women's faces. Facial averageness was negatively correlated with attractiveness in men's faces. It can be due to the fact that male facial traits indicating the level of testosterone are valued more in attractiveness judgements of the male face. Nevertheless, for those bilateral facial traits which are not tied to testosterone (e.g., location of eyes and nose) and can be associated with heterozygosity, the average should be judged as most attractive also in male faces [THORNHILL \& GANGESTAD 1993]. Women must prefer ,symmetrical” males because such males have more in-pair 
and extra-pair sexual relationships [GANGESTAD \& THORNHILL 1997].

Facial averageness goes with bilateral symmetry and the latter can be an outcome of the resistance to many environmental perturbations or insults development in morphological traits [THORNHILL \& GANGESTAD 1993]. There is little evidence of humans proving that fluctuating asymmetry is related to the resistance to different pathogens in early development. The exposure to parasites leads for example to asymmetry in the teeth [BAILIT et al. 1970] and infectious disease of mothers during pregnancy seems to be related to their infants' body asymmetry [LIVSHITS \& KOBYLIANSKY 1991].

SWADDLE \& CUTHILl [1995], undermined the role of facial FA. Changing asymmetry without altering the mean sizes of facial features, they showed that more symmetrical faces were found less attractive. It is however plausible that the symmetrical faces they produced were too unnatural i.e., expressing no emotion and hence less attractive. The problem is that they reduced not only FA but also directional asymmetry. In fact in all these face analyses it is very difficult to separate all kinds of face asymmetry and therefore FA can be rather difficult to detect in human faces [SWADDLE \& CUTHILL 1995]. FA can be simply hidden by other, larger types of face asymmetry.

RIKOWSKI \& GRAMMER [1999] found significant positive correlation between facial attractiveness and sexiness of body odor for both sexes. What is worth noting is that in their studies facial symmetry correlated positively with facial attractiveness only for males. Since RIKOWSKI \& GRAMMER [1999] found negative correlation between smell and body asymmetry for males if female raters were in the most fertile phase of menstrual cycle, they postulated that human scent may signal individual developmental stability and indicate heterozygosity reflecting better resistance against pathogens. The preference for the opposite sexes odor of MHC-dissimilar individuals, therefore for heterozygosity, was shown by WEDEKIND \& FURI [1997]. All this may mean that human scent transmits important information, which is relevant to mate choice decisions.

Despite the fact that it is difficult to disentangle facial symmetry, fluctuating asymmetry and facial averagness there are many arguments supporting "fitness" related honest signal of face attractiveness.

\section{General attractiveness}

Studies of physical attraction attributes are not always consistent, this is particularly so for facial features. Nevertheless physical attractiveness plays a great role on the human mate market and it is especially important in terms of female's mate value. UDRY \& ECKLAND [1984] found that the more attractive women were in high school, the younger their age of marriage, and the higher their household income 15 years later. It should not be surprising that more females than males deceive on these attributes [TOOKE \& CAMIRE 1991]. Summarizing the evidence from nearly 200 societies, FORD \& BEACH [1951] noticed that "physical beauty of the female receives more explicit consideration than does the handsomeness of the male". There are twice as many male than female advertisers who request a photograph of respondents. This proves that males put more stress on their prospective partner physical appearance [WIE- 
DERMAN 1993]. Generally, more women than men offer physical attractiveness in personal ads and more men than women seek cues of physical appearance in a prospective partner [BERECZKEI et al. 1997; GREENLESS, MCGREW 1994; THIESSEN et al. 1993; WAYNFORTH \& DUNBAR 1995]. Although in BLHD both sexes did not differ in offering physical appearance attributes (2-tailed $\chi^{2}=0.34$; $p<0.9$ ), they differed significantly in seeking physical appearance cues (2-tailed $\left.\chi^{2}=10.68 ; p<0.001\right)-$ males sought this trait more often. The comparison was possible for the entire male and female samples because the age distribution for both sexes did not differ significantly (Kołmogorov-Smirnov $Z=1.21, p<0.1$ ). The lack of difference for offering traits related to physical appearance could be attributed to the display strategy which might increase general attractiveness of an ad and to such trait as height which was offered quite often by men and was included in the physical attractiveness category. Using a questionnaire that listed 13 different personal advertisements for prospective mates, PAWŁOWSKI \& DUNBAR [2001] confirmed that males rate very highly both attractiveness and sexiness. Males appeared to be very concerned about physical attractiveness even in homosexual personal ads [DEAUX \& HANNA 1984].

If physical attractiveness is an honest signal of phenotypic or genetic quality then one should expect positive correlation between attractiveness of different body parts. Following this line of reasoning THORNHILL \& GRAMMER [1999] used photographs of 92 nude women from 18 to 30 years of age and assessed whether independent ratings of photographs of faces, body fronts (with face covered) and body backs of the same woman were in some way correlated. Positive correlation between face, front and body back attractiveness implies that woman's face and body shape comprise a single ornament of honest mate value [THORNHILL \& GRAMMER 1999].

Because age, hormone and developmental stability markers pertain to phenotypic and genetic quality it is unlikely that physical attractiveness can be just an arbitrary or culturally dependent concept. If attractiveness is an honest signal of prospective mate biological quality, we should agree that to the great extent physical attractiveness judgements are biologically relevant. Yet, it is also worth noting that all presented results on biological valency of physical attractiveness do not preclude greater variability in judgements of attractiveness.

\section{Socio-economic status and male market value}

In contrast to males, human female reproductive success is linked to finding a mate who is able to provide such resources as food, shelter, territory and protection [BUSS 1989]. These resources increase the chances of bringing up offspring successfully and pass genes onto next generations. Mate decisions cannot be untangled with intrasexual competition. Comparing between potential mates of the other sex and predicting their potential biological success in relation to others is also crucial to mate choice. It is particularly so when potential mates are not in short supply and their perspectives can depend on further intrasexual competition for resources.

Human commitment of "external resources" to parental care is very pronoun- 
ced. Women impose greater demands on males to provide parental care because the costs of rearing of an unusually largebrained offspring are very high in humans. Females who preferred resourceproviding mates enhanced also the reproductive advantage for offspring through increased (due to heritability) social and economic status. Females with psychological mechanisms of detecting possession of resources by potential mates and preferring such males have been probably selected for in human evolution. The fact that males clothing and ornamentation can signal wealth or social status and therefore reproductive value [LOW 1979] explains why in personal advertisements males offer quite often such characters as "well-groomed" and "sporty" [BERECZKEI et al. 1997]. In many contemporary societies these traits may be a simple and better cue of male social status than his physical attractiveness.

According to FeINGOLD [1992] in the rank order of female preferences, it is male SES which goes first, and male intelligence, humor and personality go only on further places. This of course reflects the relative importance of prospective partner traits for offspring investment. If so, one should expect that males with resources should have more mates and/or more sexual activity and therefore better reproductive success. In fact, social status or prestige is usually positively correlated with male's reproductive success [HILL 1984]. This is true especially in the societies living slightly above the subsistence level.

Females who marry higher-status mates have higher reproductive success measured by surviving children, both in pre-industrial [VOLAND \& ENGEL 1990] and industrial [BERECZKEI \& CSANAKY
1996] societies. There are also much evidence (review in BETZIG [1988]) of the correlation between male resource holding power (measured e.g., by land, livestock, capital and status) and mate number. Level of polygyny can also be predicted by hunting success in Ache [KAPLAN \& HILL 1985], chiefly rank in Ifaluk [TURKE \& BETZIG 1985] or headmanship and personal violence in Yanomamo [CHAGNON 1988].

Since reproduction can be separated from sexual behavior in the societies with surplus wealth, e.g., in Western culture, it might be that a better measure of displaying male success would be the number of sexual partners or the rate of sexual activity (still working proximate mechanisms conditioning their attractiveness for females). Males with more economic resources have in fact more sexual partners and emphasize prospective spouses' physical attractiveness more often than their less affluent peers [TOWNSEND 1993]. PERUSSE [1994] showed that in all unmarried men aged 30 years and over social status accounts for nearly $60 \%$ of the variance in frequency of simultaneous partners and for as much as $83 \%$ of the variance in lifetime number of partners for men between 30-39 years of age. This means that men with higher social status are more attractive for women and that their status seems to be the most important factor taken into consideration by the opposite sex. Female's social status does not correlate with the frequency of simultaneous partners nor with the variance in lifetime number of partners [PERUSSE 1994].

An experiment by BAR-TALE \& SAXE [1976] showed that it seems to be a common way of perception which accords with evolutionary predictions that 
when presented with pictures of couples showing attractive females and lessattractive male partners, subjects concluded that the latter had high incomes and occupational status. Females are consistently found to rate such traits as financial prospects and ambition relatively highly [BUSS 1989, 1993; HOYT \& HUDSON 1981].

Resources or financial security are offered more often by males and sought more often by females in personal advertisements [BERECZKEI et al. 1997; GREENLESS \& MCGREW 1994; HARRISON \& SAEED 1977; THIESSEN et al. 1993; WAYNFORTH \& DUNBAR 1995; WIEDERMAN 1993]. In the data from the "Observer", females sought also resources significantly more frequently than did males $(23.5 \%$ vs. $10.3 \%)$ (2-tailed $\left.\chi^{2}=32.1 ; \quad p<0.0001\right)$. Unexpectedly, women offered resources almost as frequently as men did (45.4\% vs. 50,7\%) (2-tailed $\chi^{2}=3.96 ; p<0.09$ ), yet those females who offered resources did not offer on average fewer traits than those who did not offer them $(t=0.85$, $d f=538, \quad p=0.39, \quad \mathrm{t}-\mathrm{Student}$ test for independent samples). It indicates that possessing resources by females has only minor meaning on the mate market and their understanding of it. As BAIZE \& SCHROEDER [1995] suggest, advertising traits which are usually not of interest of the opposite sex, can be due to the fact that in some cases females expect that males value the same trait (i.e., resources) as they value. It would also explain why men tend to advertise physical attractiveness so often.

On the contrary, males advertising resources were less likely to offer other traits $(t=2.53, d f=503, p<0.01)$. This may mean that when offering resources, only men feel that they are in a good bargaining position. It can be supported also by the fact that in comparison to those men who did not offer resources $(42.8 \%)$ men who did $(57.3 \%)$ sought more often attractiveness in a prospective partner $\left(2\right.$-tailed $\left.\chi^{2}=6.36 ; p<0.01\right)$. If shorter men in their 20's have higher educational achievements and therefore good financial prospects, it can recompense for their short stature (which as shown before can be a serious handicap on the mate market) [HOLL et al. 1991].

It is worth noting that longer personal advertisements are more attractive to females [THIESSEN et al. 1993]. Whether it is due to more information and longer "male display", females are interested in, as THIESSEN et al. [1993] suggest or to the indirect information of male resources and his willingness to invest more in a partner (ads are relatively costly) remains to be answered. Since males prefer shorter advertisements with the information on female attractiveness, it is also possible that the preferences for different advertisement length reflect only female long-term relationship expectation and the prevalence of male short-term relationship strategy.

In the light of the male age role for females (see earlier) it is not surprising that very young women prefer relatively young men who have not accumulated resources. PAWŁOWSKI \& DUNBAR [2001] showed that older women chose advertisements, which offered resources more often than did younger women. It does not mean, however, that young women are not concerned about resources. They seek some indicators of future male's earning potential, e.g., ambition, intelligence, industriousness and dominance [BUSS 1989]. It makes sense in terms of 
the chances of greater investments in the female herself and her offspring but also in terms of passing better genes to the next generation. The latter is of course true only in the case of at least partial heritability of the traits that lead to resource acquisition.

The other proof of females' consideration for resources is the fact that women predict that males would deceive on financial characteristics at a higher rate [KEENAN et al. 1997]. TOOKE \& CAMIRE [1991] showed that males do tend to deceive about their financial resources. The importance of male SES (measured in terms of education and occupation) for female mate decisions was also shown by LICHTER et al. [1995]. They found that even in the demographic shortages of suitable marital partners women would rather forego marriage than marry low status men!

\section{Discussion}

Human mate choice decisions are complex processes based on many available pieces of information on a prospective partner. The most important factors which are taken into consideration on the human mate market universally are age or cues of age, physical features of body and face as well as socio-economic status or resources possessed by a male. Age and physical appearance are good predictors of female fertility, and resources and personality seem to be good predictors of male's paternal investment.

An individual's value on the mate market is determined in a straightforward way by age-specific factors that influence fitness (fecundity for females and survivorship and income for males) [PAWŁOWSKI \& DUNBAR 1999b]. Since fer- tility declines with age more quickly for females, males are very concerned not only about prospective mate's age but also about all morphological traits which are age related. This was confirmed by males' preference for female's physical traits (i.e., face and body shape) indicating youth. The main problem, however, is whether males should pay more attention to the female Fisherian reproductive potential or to her current fecundity. As shown earlier, this depends on a male's age, his further life expectancy and his reproductive strategy. High human flexibility in mate search strategies in response to the frequency-dependent effects imposed by the market seems to explain cross-cultural differences in this behavior. Since in traditional societies females marry usually earlier than in the contemporary western society, their peak mate value can be shifted leftwards. On the other hand, if there is too high a risk of mortality for young men their mate value could be shifted rightwards. As PAWŁOWSKI \& DUNBAR [1999b] suggest, in such circumstances marrying a young male could be risky because he may die before the end of parental investment. In harsh conditions survival to middle age may be a simple indicator of genetic quality. In traditional societies then, the peaks in the market values of the two sexes can diverge more than in the contemporary UK or Poland. Furthermore, female's Fisherian reproductive potential is highly valued in societies where it is important to have more children (e.g., 7) because their mortality is high [BORGERHOFF MULDER 1988]. In contrast, in societies where children are costly to raise and their mortality is very low, and where females usually do not give birth to more than 3 children, males 
can be not as much concerned about female's Fisherian reproductive potential as about her current fecundity. This change of reproductive strategy (as related to the number of born children) might also explain higher concern for traits indicating immunocompetence and genetic quality. If a female gives birth usually only to two children, her offspring viability due to high genes quality can be more important than when giving birth to more children (it is a matter of probability of having at least 2 children with high genetic quality).

Female reproductive success can be disturbed in different stages of her reproduction - fertilization, long lasting pregnancy and lactation. Failure in one of them means lack of reproductive success. This explains why males are so concerned about female's body features, which seem to reflect female's age and her fertility. Adequate amount of body fat and fat distribution can reflect female's health, her endocrinological status and the amount of energy storage in fat, hence her reproductive potential. The fact that in traditional societies males prefer different female's body shape than in contemporary Western society does not mean that aesthetic canons are arbitrary but that they are conditioned by environmental conditions people live in. In environments with seasonal food shortages, it is a higher amount of female body fat and therefore higher BMI, which is preferred. The reproductive advantages of fat accumulation in such environments must overweigh the costs of fat related elevated risk of female morbidity and mortality in late adulthood. CUNNINGHAM et al. [1995] postulate for instance that American Black males prefer slightly heavier females than Whites because of "lingering uncertainties concerning resource availability in the African American community". In conditions of food plenty, an excessive amount of internal body fat storage is no longer a good predictor of female reproductive potential. In such ecological conditions moderate amount of body fat and lower WHR indicate higher female's biological value and therefore may be preferred on mate market. Males may be also concerned about these female body traits (e.g., BMI), which can reflect her age and therefore her reproductive potential. Breast size and shape has been also suggested as an indicator of female's age and fertility [GALLUP 1982], at least in those societies where breasts are usually uncovered. Altogether the preference that men show toward youth and beauty can be easily explained by the utility of these traits as predictors of fertility and infant survival [SYMONS 1979].

Facial attractiveness is not as ecologically dependent as female body shape. The fact that people agree in rating the physical attractiveness of others regardless of sex, age, SES or geographical region [BERSHEID \& WALSTER 1974] lends support for non-arbitrary perception of facial attractiveness. Facial averagness and symmetry seem to be good cues of genetic quality. They indicate developmental stability and hence resistance to adverse factors (e.g., parasites, toxins), which are usually present in the early stages of development. The fact that women with symmetrical breasts have more children (age independently) [MOLLER et al. 1995] and therefore higher reproductive success, proves biological meaning of the preference for lower fluctuating asymmetry. The biological meaning of attractiveness is also 
supported by evidence that attractiveness is valued more in pathogen prevalent environments. Positive correlation between female's face, her body front and back [THORNHILL \& GRAMMER 1999] indicates that different body parts do not convey contradictory information about female's attractiveness and supports the notion that attractiveness reflects general biological quality.

Physical attractiveness is less important for males mainly because their age, and age related morphological features are not crucial for their reproductive potential. Male's stature appeared to be important for females not because taller men have higher chances to fertilize a female, but because they seem to be better in intramale competition and have on average higher socio-economic status, which assures higher parental investment and possibly also better genes for offspring. Attractive male's facial traits seem to be related to the higher androgen level and to the stable development reflecting genetic quality. Such traits are preferred by females especially in shortterm mating strategy. This is because the traits reflecting good genes imply better offspring viability and attractiveness. They do not need, however, reflect male's willingness for parental investment, his quality as resource provider and long-term protector of female and offspring. The relatively long and costly process of rearing offspring in humans explains why when seeking for a longterm relationship, females are more concerned about male's SES, his resources or psychological attributes indicating good prospects in these terms.

The human mate market like other biological markets [NOË \& HAMMERSTEIN 1995] can be also studied as a way of exchanging commodities (i.e., benefits that one person can offer to the opposite sex partner) between both sexes. This implies different possible trade-offs on this market. Trading usually takes place on the basis of honest signals that are correlated with the access to commodity, instead of being based on the commodity [NOË \& HAMMERSTEIN 1995]. That is the reason why females offering youthfulness and therefore high Fisherian reproductive potential, can be relatively demanding on the mate market [WAYNFORTH \& DUNBAR 1995]. Female physical attractiveness not only connotes age but also health, reproductive value and in general good genes. This allows females to trade physical attractiveness for male's occupational status and resources [BERECZKEI et al. 1997]. On the other side, males with higher occupational status tend to trade it for female's physical attractiveness. The fewer resources males have the more domestic virtues (or family commitment) they offer [BERECZKEI et al. 1997]. This is also the case in traditional societies, for instance in the Aka pygmies, males in compensation for fewer resources spend more time in the direct care after their infants [HEWLETT 1988]. Higher status fathers invest less direct care in their children but by gaining more resources they can afford more than one wife and more children! Females can trade commitment against both attractiveness and resources by males because there are two possible ways of paternal investment: in the form of commitment to the relationship and offspring or in the form of resources, which the woman can invest in her offspring. Since female's attractiveness is an overriding concern for the opposite sex, males do not trade this trait 
for anything else [PAWŁOWSKI \& DUNBAR 2001]. Individuals who have in general low market value are less demanding [PAWŁOWSKI \& DUNBAR 1999b]. These trade-off strategies support the notion of the importance of age and attractiveness for females and SES for males. What is more, trade-off strategies indicate that human demands on the mate market are close to optimal. People judge their chances on the mate market and try to attune their requirements to their "market value". Optimal mate choice involves also a trade-off between mate numbers and mate quality. This means that depending on the sex ratio and the degree of quality variation of the opposite sex, both sexes may be less or more choosy. If one sex has lower rate but has sufficiently high quality variation, members of the more competitive sex might also be choosy [ANDERSON \& IWASA 1996]. Although then men are usually the more competitive sex, in some cases, e.g., after a war when males can be decimated, females can be less choosy. PAWŁOWSKI et al. [2000] showed that only in the cohort of males who entered the mate market after the Second War World, so at the time of biased sex ratio, when compared with their taller peers, shorter men were not handicapped on the mate market. Their chances to leave at least one child were not lower than for taller men. Mate choice decisions are frequency dependent and we should not forget that in the real mate markets, people face with many restrictions of the mate choice they have. It is why they need to attune their preferences and requirements to the accessible pool of potential partners and to their own mate market value.

The evolved psychological mechanisms which lay behind mate choice de- cisions in different ecological conditions do not need to be conscious [BUSS 1995]. People are usually not aware of biological meaning and therefore of the real, ultimate reason of their preference for some traits in the opposite sex. For instance, individuals may perceive attractiveness in a holistic way and do not focus on some facial attributes or their meaning and therefore they are unable to articulate the linkage between attraction to a face and any adaptive significance of facial features [CUNNINGHAM et al. 1995]. Evolution promoted preferences and sensitiveness to some traits because they have probably been positively related to the reproductive success. PERUSSE [1993] showed that males convert their position in the occupational structure (measured by their income, prestige and power) into the proximal measure of reproductive success, which is mating. Due to contraception, however, their mating success does not need to be converted into reproductive success. This means that evolution promoted mate choices directed by some particular preferences, without "revealing" direct ultimate evolutionary reasons of such decisions.

In the light of presented evidences on the perception of attractiveness as well as on physiological or genetic correlates of many morphological "attractive" features, one could conclude that the factors usually influencing mate choice decisions are reliable cues of biological value. Thus, as evolutionary theory predicts, human mate choice decisions seem to be based mainly on the traits, which are reproductively relevant and offspring "fitness" related. However, we should also remember that reproductive value is not ideally reflected by different traits 
statistically considered as attractive. What is perceived as attractive does not need to guarantee high reproductive success and what is judged as unattractive does not mean low reproductive value. Firstly, usually preferred traits are not $100 \%$ cue of reproductive value. As in the case of many proximate biological mechanisms, discussed biological predictors are less effective as one could expect. Secondly, there is always a risk of dishonest signaling promoted by selection e.g., facial neotenous supernormal cues of youth [JONES 1995] can be sometimes misleading marker of female's age. Thirdly, since environmental and social conditions can change quite dramatically, we can face with the situation when one sex's preferences are no longer adaptive or they are not understandable by the opposite sex. In different environmental conditions and in different parental or reproductive strategies we can expect different preferences. In relatively promiscuous English society, many young males value female's commitment as much as attractiveness and as PAWŁOWSKI \& DUNBAR [2001] showed, females underestimate males' concern with commitment. The males' interest in such social conditions can be a reflection of mateguarding behavior and low paternity certainty [PAWŁOWSKI \& DUNBAR 2001].

The traits discussed here and their biological relevance cannot of course explain the whole variance of the human mate preferences. Perception of attractiveness is influenced not only by biological and socio-cultural factors, but also by individual personality and motivational dynamics as well [CUNNINGHAM et al. 1995]. There are also many other traits and mechanisms, which can influence mate preferences and therefore mate choice decisions, e.g., expressive and grooming features [CUNNINGHAM et al. 1995], negative or positive assortative mating as well as bad or good personal experiences with previous partners. Human mate choice behavior in the complex human societies seems to be more complicated than in many other animals and therefore warrants further studies on this subject.

\section{Acknowledgements}

I wish to thank Stanley Ulijaszek for the remarks that improved the paper markedly. I would also like to thank Bernie Harper for his helpful suggestions, Elżbieta Cieplak and Monika Mazurkiewicz for their great help in the data collection, and Jerzy Lewandowski for the access to the "Cmok" marriage bureau data.

\section{References}

Aвbot R.D., L.R. White, G. Webster Ross, et al., 1998, Height as a marker of childhood development and late-life cognitive function: The Honolulu-Asia aging study, Pediatrics, 102, 602-609

Allbeck P., C. Bergh, 1992, Height, body mass and mortality; do social factors explain the association?, Public Health, 106, 375-82

Anderson J.L., C.B. Crawford, J. Nadean, T. LiNDBERG, 1992, Was the Duchess of Windsor right? A cross-cultural review of the sociobiology of ideals of female body shape, Ethol. Sociobiol., 13, 197-227

ANDERSON M., Y. IwASA, 1996, Sexual selection, TREE, 11, 53-58

Bailit H.L., P.L. Workman, J.D. Niswander, J.C. MACleAN, 1970, Dental asymmetry as an indicator of genetic and environmental conditions in human populations, Hum. Biol., 42, 626-638

Baize H.R., J.E. Schroeder, 1995, Personality and mate selection in personal ads: evolutionary preferences in a public mate selection process, J. Soc. Behav. Pers. 10, 517-536 
Bar-Tale D., L. SaXe, 1976, Perceptions of similarity and dissimilarity physically attractive couples and individuals, J. Pers. Soc. Psychol., 33, 722-781

BereczKei T., A. CsanaKy, 1996, Mate choice marital success, and reproduction in a modern society, Ethol. Sociobiol., 17, 23-35

Bereczkei T., S. Voros, A. Gal, L. Bernath, 1997, Resources, attractiveness, family commitment; reproductive decisions in human mate choice, Ethology, 103, 681-699

Bersheid E., E. Walster, 1974, Physical Attractiveness, [in:] Advances in experimental social psychology, L. Berkewitz (ed.), Acad. Press, New York, pp. 157-215

BeTZIG L.L., 1988, Mating and parenting in Darwinian perspective. [in:] Human Reproductive Behaviour: A Darwinian Perspective, L. Betzig, M. Borgerhoff Mulder \& P. Turke (eds.), Cambridge Univ. Press, Cambridge, pp 3-20

BIELICKI T., J. ChARZEWSKI, 1983, Body weight and upward social mobility, Ann. Hum. Biol., 10, 403-408

Bielicki T., A. WaliszKo, 1992, Stature, upward social mobility and the nature of statural differences between social classes, Ann. Hum. Biol., 19, 589-593

BJöRNTORP P., 1988, The associations between obesity, adipose tissue distribution and disease, Acta Medica Scandinavica, (Suppl.), 723, 121-134

BORGERHOFF MuldER M., 1988, Kipsigis bridewealth payments, [in:] Human Reproductive Behaviour, L.Betzig, M. Borgerhoff Mulder \& P.Turke (eds.), Cambridge University Press, Cambridge, pp. 65-82

Buss D., 1989, Sex differences in human mate preferences: Evolutionary hypotheses tested in 37 cultures, Behav. Brain Sci., 12, 1-49

Buss D., 1993, The evolution of desire, New York: Basic Books

Buss D., 1995, Evolutionary psychology: A new paradigm for psychological science, Psychological Inquiry, 6, 1-30

CHAGNON N.A., 1988, Life histories, blood revenge, and warfare in a tribal population, Science, 239, 985-992

CHASE H.C., 1969, Infant mortality and weight at birth: 1960 United States cohort, Am. J. Pub. Hlth, 59, 1618-1628

Choiniere R, P. LAFOnTAINe, A.C. Edwards, 2000, Distribution of cardiovascular disease risk fac- tors by socioeconomic status among Canadian adults, Can. Med. Assoc. J., 162, Suppl., 13-24

Cronin H., 1991, The ant and the peacock, Cambridge Univ. Press, Cambridge

Cunningham A.S., D.B. Jelliffe, E.F. Jelliffe, 1991, Breast-feeding and health in the 1980s: a global epidemiological review, J. Pediatr., 118, $1-8$

CunNingham M.R., 1986, Measuring the physical in physical attractiveness: Quasi-experiments on the sociobiology of female attractiveness, J. Pers. Soc. Psychol., 50, 925-935

Cunningham M.R., A.P. Barbee, C.L. Pike, 1990, What do women want? Facialmetric assessment of multiple motives in the perception of male facial attractiveness, J. Pers. Soc. Psychol., 59, 61-72

Cunningham M.R., A.R. Roberts, C.H. Wu, A.P. BARBEe, P.B. DRUEN, 1995, "Their ideas of beauty are, on whole, the same as ours": Consistency and variability in the cross-cultural perception of female physical attractiveness, J. Pers. Soc. Psychol., 68, 261-279

DeauX K., R. HANNA, 1984, Courtship in the personals column: The influence of gender and sexual orientation, Sex Roles, 11, 363-375

DeRidder C.M., P.F. BRUning, M.L. ZoNDERLAND, et al., 1990, Body-fat mass, body-fat distribution, and plasma hormones in early puberty in females, J. Clin. Endocrinol. Metabol., 70, 888-893

DeScrilli A., A. Bossi, E. Marubini, M. CACAMO, 1983, Neonatal morbidity risk: A study of the relationship to birthweight and gestational age in four Italian centres, Ann. Hum. Biol., 10, 235-246

ELLIS B.J., 1992, The evolution of sexual attraction: Evaluative mechanisms in women, [in:] The adopted mind, J. Barkow, L. Cosmides \& J. Tooby (eds.), Oxford Univ. Press, New York, pp. 267-288

FEINGOLD A., 1992, Gender differences in mate selection preferences: A test of parental investment model, Psychol. Bull., 112, 125-139

FISHER R.A., 1930, The genetical theory of natural selection, Clarendon Press, Oxford (revised edition from 1958)

Folsom A.R., S.A. Kaye, T.A. Seller, et al., 1993, Body fat distribution and 5-year risk of death in older women, J. Am. Med. Ass., 269, 483-487 
Folstad I., A.J. KARTER, 1992, Parasites, bright males and the immunocompetence handicap, Am. Nat., 139, 603-622

Forbes G.F., 1987, Human body composition. Growth, aging, nutrition and activity, Springer-Verlag, New York

FORD C.S., F. BEACH, 1951, Patterns of sexual behavior, Harper, New York

Furnham A., T. TAN, C. MCMANUS, 1997, Waistto-hip ratio and preferences for body shape: $A$ replication and extension, Personality and Individual Differences, 22, 539-549

Gallup G.G. JR., 1982, Permanent breast enlargement in human females: a sociobiological analysis, J. Hum. Evol., 11, 597-601

Gangestad S.W., D.M. Buss, 1993, Pathogen prevalence and human mate preference, Ethol. Sociobiol., 14, 89-96

Gangestad S.W., R. Thornhill, 1997, The evolutionary psychology of extrapair sex: the role of fluctuating asymmetry, Evol. Hum. Behav., 18, 69-88

Golding J., I.S. Rogers, P.M. EMmetT, 1997, Association between breast feeding, child development and behaviour, Early Human Development, 49 Suppl., 175-184

Goldman N., M. MontgOMERy, 1989, Fecundability and husband's age, Social Biology, 36, 146-166

Graziano W.G., T. Brothen, E. Bescheid, 1978, Height and attraction" Do men and women see eye-to-eye?, Journal of Personality, 46, 128-145

GreenleEs I.A., W.C. McGrew, 1994, Sex and age differences in preferences and tactics of mate attraction: analysis of published advertisements, Ethol. Sociobiol., 15, 59-72

Hachisuga T., A. Kaetsu, H. Sugimori, T. KAMURA, M. TSUneyoshi, T. KaWARABAYASHI, 1998, Risk factors for endometrial cancer in Japanese women, Int. J. Gynecol. Cancer, 8, 292-297

HARRISON A.A., L. SAEED, 1977, Let's make a deal: An analysis of revelations and stipulations in lonely hearts advertisements, J. Pers. Soc. Psychol., 35, 257-264

HAMMERSTEIN P., (in press), Games and markets: economic behaviour in humans and other animals, [in:] „Economics in Nature. The evolutionary biology of economic behaviour", R. Noe, J. van Hoof \& P. Hammerstein (eds.), Cambridge Univ. Press, Cambridge
Hewlett B.S., 1988, Sexual selection and parental investment among Aka pygmies, [in:] Human Reproductive Behaviour, L. Betzig, M. Borgerhoff Mulder \& P. Turke (eds.), Cambridge University Press, Cambridge, pp. 263-276

Hill J., 1984, Prestige and reproductive success in man, Ethol. Sociobiol., 5, 77-95

Holl R.W., H. Schroder, E. Heinze, 1991, Are short boys disadvantaged as adults - a reevaluation of 77 men with constitutional growth delay and (or) familial short stature, Deutsche Medizinische Wochenschrift, 116, 928-934

Hoyt L.L., J.W. Hudson, 1981, Personal characteristcs important in mate preference among college students, Soc. Behav. Pers., 9, 93-96

HuAng Z.P., W.C. Willett, J.E. MANSON, et al., 1998, Body weight, weight change, and risk for hypertension in women, Ann. Intern. Med., 128, 81

JAŁKIEWICZ M., 1997, Perception of fatness, Przegląd Antropol. - Anthropol. Rev., 60, 75-88

JONES D., 1995, Sexual selection, physical attractiveness, and facial neoteny: Cross-cultural evidence and implications, Curr. Anthropol., 36, 723-748

KAPLAN H., K. HiLl, 1985, Hunting ability and reproductive success among male Ache foragers: Preliminary results, Curr. Anthropol., 26, 131-133

Kaye S.A., A.R. Folsom, R.J. Prineas, J.D. POTTER, S.M. GAPSTUR, 1990, The association of body fat distribution with lifestyle and reproductive factors in a population study of postmenopausal women, Int. J. Obesity, 14, 583-591

Kee F., V. Nicaud, L. Tiret, A. Evans, D. O'REILly, 1997, Short stature and heart disease: nature or nurture?, Int. J. Epidemiol., 26, $748-756$

KeEnan J.P., G.G. Gallup JR., N. Goulet, M. KULKARNI, 1997, Attributions of deception in human mating strategies, J. Soc. Behav. Pers., 12, 45-52

KendRICK K.M., M.R. Hinton, K. AtKInS, 1998, Mothers determine sexual preferences, Nature, 395, 229-230

KENRICK D., 1994, Evolutionary social psychology: From sexual selection to social cognition, Adv. Exp. Soc. Psychol., 31, 75-121 
KenRICK D.T., R.C. KeEFe, 1992, Age preferences in mates reflects sex differences in human reproductive strategies, Behav. Brain Sci., 15, 75-133

KoOps B.L., L.J. Morgan, F.C. BAtaglia, 1982, Neonatal mortality risk in relation to birth weight and gestational age: Update, Pediatrics, 101, 969-977

KujawA B., 1998, Atrakcyjność fizyczna. Biologiczne podstawy preferencji estetycznych, Monografie Instytutu Antropologii UAM, 2, Poznań

Kujawa B., J. StrzalKo, 1998, Standard of physical attractiveness, Przegląd Antropol. Anthropol. Rev., 61, 31-48

LaKe J.K., C. Power, T.J. Cole, 1997, Child to adult body mass index in the 1958 British birth cohort: associations with parental obesity, Arch. Dis. Child., 77, 376-381

LANGlois J.H., L.A. RogGman, R.J. CASEY, J.M RITTER, 1987, Infant preferences for attractive faces: Rudiments of a stereotype?, Dev. Psychol., 23, 363-369

Langlois J.H., L.A. Roggman, 1990, Attractive faces are only average, Psychol. Sci., 1, 115121

Langlois J.H., L.A. Roggman, L. Musselman, 1994, What is average and what is not average about attractive faces?, Psychol. Sci., 5, 214220

LEIBEL R.L., N.K. EDENS, S.K. FRIED, 1989, Physiologic basis for the control of body fat distribution in humans, Annu. Rev. Nutr., 9 417-443

Liao Y., D.L. Mcgee, G. CaO, R.S. Cooper, 1996, Short stature and risk of mortality and cardiovascular disease: negative findings from the NHANES I epidemiological follow-up study, J. Am. Coll. Cardiol., 27, 678-682

LiCHTER D.T, R.N. ANDERSON, M.D. HAYWARD, 1995, Marriage markets and marital choice, J. Fam. Issues, 1995, 16, 412-431

Livshits G., E. KoBYLIANSKY, 1991, Fluctuating asymmetry as a possible measure of developmental homeostasis in humans: A review, Hum. Biol., 63, 441-466

Low B.S., R.D. AleXANDER, K.M. NOONAN, 1987, Human hips, breasts and buttocks: Is fat deceptive?, Ethol. Sociobiol., 8, 249-257

LynN M., B.A. ShuRGot, 1984, Responses to lonely hearts advertisements: Effects of reported physical attractiveness, physique, and coloration, Pers. Soc. Psychol. Bull., 10, 349357

MANNING J.T. 1995, Fluctuating asymmetry and body weight in men and women: implications for sexual selection, Ethol. Sociobiol., 16, 145153

ManinNG J.T., R.L. Trivers, D. Singh, R. THORNHILL, 1999, The mystery of female beauty, Nature, 399, 214-215

Mathes E.W., S.M. Brennan, P.M. Haugen, H.B. Rice, 1985, Ratings of physical attractiveness as a function of age, J. Soc. Psychol., 125, 157-168

MAZur A., C. HALPer, J.R. UdRY, 1994, Dominant-looking male teenagers copulate earlier, Ethol. Sociobiol., 15, 87-94

McDade T.W., C.M. Worthman, 1999, Evolutionary process and the ecology of human immune function, Am. J. Hum. Biol., 11, 705-717

Meyer H.E., R. Selmer, 1999, Income, educational level and body height, Ann. Hum. Biol., 26, 219-227

Moller A.P., M. Soler, R. Thornhill, 1995, Breast asymmetry, sexual selection and human reproductive success, Ethol. Sociobiol., 16, 207-219

Mueller U., A. Mazur, 1997, Facial dominance in Homo sapiens as honest signaling of male quality, Behav. Ecol., 8, 569-579

NoË R., P. HAMmerstein, 1995, Biological markets, TREE, 10, 336-339

Nö̈ R., J. VAN HoOf, P. Hammerstein, 2001, Economics in Nature. The evolutionary biology of economic behaviour, Cambridge Univ. Press, Cambridge (in press)

PAWŁOWSKI B., 1998, Why are human newborns so big and fat? Hum. Evol., 13, 65-72

PAWŁowsKi B., R.I.M. DunBAR, 1999a, Withholding age as putative deception in mate search tactics, Evol. Hum. Behav., 20, 53-69

PAWŁOWSKi B., R.I.M. DuNBAR, 1999b, Impact of market value on human mate choice decisions, Proc. R. Soc. Lond. B., 266, 281-285

PaWŁowski B., R.I.M. Dunbar, (in press), $H u$ man mate choice strategies, [in:] ,Economics in Nature. The evolutionary biology of economic behaviour" R. Noe, J. van Hoof \& P. Hammerstein (eds.), Cambridge Univ. Press, Cambridge

PawŁowski B., R.I.M. Dunbar, A. Lipowicz, 2000, Tall men have more reproductive success, Nature, 403, 156 
PeCK A.M., D.H. VAgero, 1989, Adult body height, self perceived health and mortality in the Swedish population, J. Epidemiol. Community Health, 43, 380-384

Perrett D.I., K.J. Lee, I. Penton-Voak, et al., 1998, Effects of sexual dimorphism on facial attractiveness, Nature, 394, 884-887

Perusse, D. 1993, Cultural and reproductive success in industrial societies: Testing the relationship at the proximate and ultimate levels, Behav. Brain Sci., 16, 267-322

Perusse, D. 1994, Mate choice in modern societies: testing evolutionary hypotheses with behavioral data, Human Nature, 5, 255-278

PierCe C.A., 1996, Body height and romantic attraction: A meta-analytic test of the maletaller norm, Soc. Behav. Pers., 24, 143-149

PotTs M., R. SHORT, 1999, Ever since Adam and Eve: The evolution of human sexuality, Cambridge Univ. Press, Cambridge

QvisT J., S.E. JOHANSSON, L.M. JOHANSSON, 1996, Multivariate analyses of mortality from coronary heart disease due to biological and behavioural factors, Scand. J. Soc. Med., 24, 67-76

RajeCKi D.W., S.B. Bledsoe, J.L. Rasmussen, 1991, Successful personal ads - gender differences and similarities in offers, stipulations and outcomes, Basic and Applied Social Psychology, 12, 457-469

Rikowski A., K. Grammer, 1999, Human body odour, symmetry and attractiveness, Proc. Roy. Soc. Lond. B, 266, 869-874

Rolland-CaChera M.F., T.J. Cole, M. SEMPE, J. Ticher, C. Rossignol, A. Charraud, 1991, Body mass index variations: centiles from birth to 87 years, Eur. J. Clin. Nutr., 45, 13-21

SAPPENFIEld W.M., J.W. BuEhler, N.J. BinKIN, L.T. Strauss, C.J.R. Hogue, 1987, Differences in neonatal and postnatal mortality, by race, birth weight and gestational age, Pub. Hlth Rep., 102, 182-192

SChumacher A, R. KNussman, 1979, Are the differences in stature between social classes a modification or an assortment effect?, J. Hum. Evol., 8, 809-812

Silventoinen K., E. LAhelma, O. RhKonen, 1999, Social background, adult body-height and health, Int. J. Epidemiol., 28, 911-918

SINGH D., 1993a, Adaptive significance of female physical attractiveness: role of waist-to-hip ratio, J. Pers. Soc. Psychol., 65, 293-307
SINGH D., 1993b, Body shape and women's attractiveness. The critical role of waist-to-hip ratio, Human Nature, 4, 297-321

SMuts R.W., 1992, Fat, sex, class, adaptive flexibility, and cultural change, Ethol. Sociobiol., 13, 523-542

Steyn N.P., M. Senekal, S. Brits, M. Alberts, T. Mashego, J.H. Nel, 2000, Weight and health status of black female students, S. Afr. Med. J., 90, 146-152

StrZAŁKo J., K.A. KaszYCKa, 1988, Atrakcyjność fizyczna - obiektywne i subiektywne sktadowe oceny, Przegląd Antropol., 54, 7-17

StrzalKo J., K.A. KaszyckA, 1992, Physical attractiveness: Interpersonal and intrapersonal variability of assessments, Social Biology, 39, 170-176

SwaddLE J.P., I.C. CuTHILl, 1995, Asymmetry and human facial attractiveness: symmetry may not always be beautiful, Proc. Roy. Soc. Lond. B, 261, 111-116

Symons D., 1979, The evolution of human sexuality, Oxford Univ. Press, Oxford

Symons D., 1995a, Beauty is in the adaptations of the beholder: The evolutionary psychology of human female sexual attractiveness, [in:] Sexual Nature Sexual Culture, P.R Abramson \& S.D. Pinkerton (eds.), Univ. of Chicago Press, Chicago, pp. 80-118

Symons D. $1995 b$, comment to Jones D., Sexual selection, physical attractiveness, and facial neoteny: Cross-cultural evidence and implications, Curr. Anthropol., 36, 742

TASSINARy L.G., K.A. HANSEN, 1998, A critical test of the waist-to-hip ratio hypothesis of female physical attractiveness, Psychol. Sci., 9, 150-155

Teasdale T.W., D.R. Owen, T.I.A. Sörensen, 1991, Intelligence and educational level in adult males at the extremes of stature, Hum. Biol., 63, 19-30

Thiessen D., R.K. Young, R. Burroughs, 1993, Lonely hearts advertisements reflect sexually dimorphic mating strategies, Ethol. Sociobiol., 12, 209-229

Thornhill R., S.W. Gangestad, 1993, Human facial beauty: averageness, symmetry and parasite resistance, Human Nature, 4, 237269

Thornhill R., K. Grammer, 1999, The body and face of woman: one ornament that signals quality?, Evol. Hum. Behav., 20, 105-120 
Thornhill R., A.P. Moller, 1997, Developmental stability, disease and medicine, Biol. Rev., 72, 497-548

Tooke W., L. CAmire, 1991, Patterns of deception in intersexual and intrasexual mating strategies, Ethol. Sociobiol., 12, 345-364

TOVEe M.J., P.L. CORNELISSEN, 1999, The mystery of female beauty, Nature, 399, 215-216.

TOWNSEND J.M., 1993, Sexuality and partner selection: Sex differences among college students, Ethol. Sociobiol., 14, 305-330

Turke P.W., L. Betzig, 1985, Those who can do: Wealth, status, and reproductive success on Ifaluk, Ethol. Sociobiol., 6, 79-87

Tuvemo T., B. Jonsson, I. Persson, 1999, Intellectual and physical performance and morbidity in relation to height in a cohort of 18-year-old Swedish conscripts, Horm. Res., 52, 186-191

UDRY J.R., B.K. ECKLAND, 1984, Benefits of being attractive: differential payoffs for men and women, Psychological Reports, 54, 47-56

Van Valen L., 1962, A study of fluctuating asymmetry and sexual selection, Evolution, 16, $125-142$

Vermeulen A., 2000, Andropause, Maturitas, 34, $5-15$

Vermeulen A., J.M. Kaufman, 1995, Ageing of the hypothalamo-pituitary-testicular axis in men, Horm. Res., 43, 25-28

Voland E., C. Engel, 1990, Female choice in humans: a conditional mate selection strategy of the Krumhorn women (Germany, 17201874), Ethology, 84, 144-154.

WAALER H.T., 1984, Height, weight and mortality, Acta Med. Scand., 679 (suppl.), 1-56
Walster E., V. Aronson, D. Abrahams, L. ROTTMAN, 1966, Importance of physical attractiveness in dating behavior, J. Pers. Soc. Psychol., 4, 508-516

WAYNFORTh D., R.I.M. DunBar, 1995, Conditional mate choice strategies in humans: evidence from "Lonely hearts' advertisements", Behaviour, 132, 755-779

WEDEKIND C., I. FOLSTAD, 1994, Adaptive or nonadaptive immunosuppression by sex hormone, Am. Nat., 139, 603-622

WEDEKIND C., S. FuRI, 1997, Body odour preferences in men and women: do they aim for specific MHC combinations or simply heterozygosity?, Proc. Roy. Soc. London B, 264, 1471-1479

Wetsman A., F. Marlowe, 1999, How universal are preferences for female waist-to-hip ratios? Evidence from the Hadza of Tanzania, Evol. Hum. Behav., 20, 219-228

WIDEMO F., 1999, Beauty is in the eye of beholder: causes and consequences of variation in mating preferences, TREE, 14, 26-31

WiEDERMAN M.W., 1993, Evolved gender differences in mate preferences: Evidence from personal advertisements, Ethol. Sociobiol., 14, 331-352

YU D.W., G.H. ShEPARD JR., 1998, Is beauty in the eye of the beholder?, Nature, 396, 321-322

ZaAdstra B.M., J.C. SEIDELl, P.A.H. VANNOORD, et al., 1993, Fat and female fecundity prospective-study of effect of body-fat distribution on conception rates, Br. Med. J., 306, 484-487

Zahavi A., A. Zahavi, 1997, The handicap principle, Oxford Univ. Press, Oxford

\section{Streszczenie}

Podejmując decyzje o wyborze partnera ludzie kierują się wieloma kryteriami. Cechy, które okazały się uniwersalne, czyli istotne przy wyborze partnera we wszystkich badanych społecznościach to wiek, fizyczna atrakcyjność i posiadane zasoby potencjalnego partnera. Cechy osobowości oczywiście nie są bez znaczenia, jednak w większym stopniu zależą one od różnych warunków środowiskowych (w tym kulturowych) i strategii reprodukcyjnej niż analizowane w pracy czynniki. Wiek, cechy morfologiczne związane z budową ciała i atrakcyjnością twarzy oraz - w przypadku mężczyzn - status społeczno-ekonomiczny (SES) są rozpatrywane w kontekście ich biologicznej wartości, czyli w związku z osobniczym potencjałem reprodukcyjnym.

Oryginalne wyniki prezentowane w pracy są oparte na trzech niezależnych bazach danych: (1) dane z 1045 ogłoszeń matrymonialnych zamieszczonych w brytyjskim piśmie „Observer” 
między jesienią 1995 a wiosną 1996 roku; (2) dane z 2008 ogłoszeń matrymonialnych zamieszczonych w „Gazecie Robotniczej” między 1994 a 1996 rokiem; (3) dane z ankiet wypełnionych przez 892 kobiety, głównie w przychodniach „Zdrowego Dziecka” we Wrocławiu. Do analizy wzięto tylko 728 kobiet, które nie miały ciąży mnogiej i podały wszystkie wymagane informacje (wiek, wysokość ciała, przedciążowy ciężar ciała, obwód talii i bioder oraz takie dane dziecka, jak masa urodzeniowa).

Ponieważ płodność kobiety maleje z wiekiem o wiele szybciej niż u mężczyzny, wiek kobiety ma dużo większe znaczenie na rynku matrymonialnym. Ma to swoje odzwierciedlenie zarówno w wysokości kałymu, jaki w społecznościach tradycyjnych płaci się w zależności od wieku wybranki jak i w preferencjach mężczyzn, określanych w ofertach matrymonialnych, w społeczeństwie zachodnim. Mężczyźni wraz z wiekiem preferują stosunkowo coraz młodsze partnerki (patrz rys. 1A,B). Świadome znaczenia tej cechy, kobiety istotnie częściej niż mężczyźni ukrywają swój wiek, i to tym częściej im bardziej zbliżają się do końca okresu reprodukcji. Taka strategia pozwala im jednak zwiększać wymagania względem potencjalnych partnerów, na przykład w ofertach matrymonialnych (efekt „ukrytego wieku”). Preferencje mężczyzn co do wieku partnerki mogą być związane albo z potencjałem reprodukcyjnym (pozostała długość okresu reprodukcyjnego kobiety) albo z bieżącą płodnością kobiety (wiek w którym kobiety rodzą najwięcej dzieci). Preferencje te zależą od wieku mężczyzny, jego strategii reprodukcyjnej (krótko- lub długoterminowe związki) i warunków ekologicznych (gdy śmiertelność dzieci jest niska, kobieta nie musi ich rodzić tak wiele - na przykład 7 - i dlatego mniejsze znaczenie może mieć jej bardzo młody wiek, a co za tym idzie potencjał reprodukcyjny). Wiek mężczyzny ma znaczenie dla kobiety raczej w związku z dalszym oczekiwanym trwaniem jego życia i gwarancjami inwestycji rodzicielskich w następnych latach, niż ze względu na jego płodność (ta utrzymuje się nawet powyżej 75 roku życia). „Wartość rynkową” obu płci w zależności od wieku obrazuje rys. 2, a zmianę wymagań obu płci z wiekiem rys. 3. Wiek jest tą cechą na rynku matrymonialnym, która ma niekwestionowane znaczenie biologiczne.

Biologiczne znaczenie fizycznej atrakcyjności jest bardziej kontrowersyjne. Oprócz poglądu, że ma ona arbitralne (kulturowe) znaczenie, jest kilka koncepcji próbujących w inny sposób wyjaśnić jej znaczenie. Wiele danych wskazuje na to, że poziom atrakcyjności, zarówno sylwetki jak i twarzy kobiety, może odzwierciedlać po pierwsze jej wiek (rys. 4 obrazuje zależność BMI - wsk. masy ciała - i wieku u kobiet), a zatem jej potencjał reprodukcyjny, po drugie poziom hormonów, a więc status reprodukcyjny, po trzecie wreszcie jej odporność immunologiczną na różne czynniki zaburzające rozwój, a zatem jakość jej genotypu. Poza tą ostatnią właściwością, atrakcyjność mężczyzn ma związek przede wszystkim z cechami które są dodatnio skorelowane $\mathrm{z}$ jego zdrowiem i statusem społeczno-ekonomicznym (na przykład z wysokością ciała) oraz z cechami wskazującymi na odpowiedni poziom androgenów, który jak się zdaje, odgrywa często istotną rolę w rywalizacji w obrębie tej płci. Preferencje w stosunku do budowy ciała kobiet mogą zależeć od warunków środowiska. Na przykład w warunkach sezonowych niedostatków pokarmu, preferowane mogą być kobiety z względnie dużą ilością tkanki tłuszczowej, która jest rezerwuarem energii i zapewnia lepszy przebieg ciąży i laktacji przy brakach pokarmu. Gdy nie ma ryzyka głodu, mniej ceniona będzie duża zawartość tkanki tłuszczowej, której nadmiar zwiększa ryzyko zachorowań, na przykład na choroby układu krążenia, a bardziej odpowiedni jej rozkład (niskie WHR - stosunek obwodu talii do bioder).

Ostatnia analizowana cecha to posiadane zasoby lub cechy wskazujące na możliwość ich posiadania w przyszłości przez mężczyzn. Preferencje kobiet w stosunku do wyższego SES potencjalnego partnera są uniwersalne, bowiem wysoki poziom SES zapewnia odpowiednią 
ilość zasobów dla nich i ich potomstwa. Gdy jednak kobiety są niezbyt silnie uzależnione ekonomicznie od mężczyzn, mogą też wybierać mężczyzn z mniejszymi zasobami, ale za to zapewniających silne przywiązanie do dzieci i inwestowanie czasu w opiekę nad nimi. Potwierdzeniem biologicznego znaczenia analizowanych w pracy cech jest również traktowanie ich jako swoistego „towaru” na rynku partnerskim. I tak na przykład, bardzo młode i atrakcyjne kobiety mogą być bardziej ,wybredne” co do zasobów partnera, a mężczyźni o wysokim statusie społecznym mogą wymagać od kobiet większej atrakcyjności niż ich biedniejsi rówieśnicy. Za hipotezą o dużym biologicznym znaczeniu cech preferowanych u płci przeciwnej przemawia więc wiele argumentów. Co więcej, hipoteza ta nie wyklucza mechanizmu ,atrakcyjności” zaproponowanego przez Fishera. Jeśli działa, to mechanizm selekcji fisherowskiej może być po prostu skuteczniejszy gdy dotyczy cech o znaczeniu adaptatywnym. 